Article

\title{
Long-Term Trends and Temporal Synchrony in Plankton Richness, Diversity and Biomass Driven by Re-Oligotrophication and Climate across 17 Danish Lakes
}

\author{
Korhan Özkan 1,2,3,*, Erik Jeppesen ${ }^{1,4,5}$, Thomas A. Davidson ${ }^{1,2}$, Rikke Bjerring ${ }^{1}$, \\ Liselotte S. Johansson ${ }^{1}$, Martin Søndergaard ${ }^{1}$, Torben L. Lauridsen ${ }^{1,6}$ and \\ Jens-Christian Svenning ${ }^{2}$ \\ 1 Freshwater Ecology Group, Department of Bioscience, Aarhus University, Silkeborg 8600, Denmark; \\ ej@bios.au.dk (E.J.); thd@bios.au.dk (T.A.D.); rbh@clin.au.dk (R.B.); lsj@bios.au.dk (L.S.J.); \\ ms@bios.au.dk (M.S.); tll@bios.au.dk (T.L.L.) \\ 2 Section for Ecoinformatics and Biodiversity, Department of Bioscience, Aarhus University, Aarhus 8000, \\ Denmark; svenning@biology.au.dk \\ 3 Institute of Marine Sciences, Middle East Technical University, Erdemli, Mersin 33340, Turkey \\ 4 Greenland Climate Research Centre, Greenland Institute of Natural Resources, Nuuk 3900, Greenland \\ 5 Sino-Danish Centre for Education and Research, Beijing 100190, China \\ 6 Arctic Research Centre, Aarhus University, Aarhus 8600, Denmark \\ * Correspondence: okorhan@metu.edu.tr; Tel.: +90-324-521-2406 (ext. 1401)
}

Academic Editor: Wayne O'Connor

Received: 27 August 2016; Accepted: 22 September 2016; Published: 28 September 2016

\begin{abstract}
A two-decade (1989-2008) time series of lake phyto- and zooplankton, water characteristics and climate in 17 Danish lakes was analysed to examine the long term changes and the effects of lake restoration efforts. The analyses of the pair-wise correlations across time series revealed a strong synchrony in climatic variables among the lakes. A significant, but weak increase in air temperature was observed and resulted in a corresponding increase in surface water temperature only in summer. Lake physico-chemical variables had weaker synchrony than climatic variables. Synchrony in water temperature and stratification was stronger than lake chemistry as the former is mostly affected by atmospheric energy flux. Synchrony in the taxonomic richness of the plankton groups and phytoplankton biomass was apparent, to a similar degree as observed for lake chemistry. The synchrony and the temporal trends in lake chemistry and plankton were more pronounced for the lakes with strong re-oligotrophication. Phytoplankton biomass decreased and plankton richness increased in these lakes, with a shift from Chlorophyta dominance towards more heterogeneous phytoplankton communities. Notably, a widespread significant positive trend in plankton richness was observed not only in lakes with strong re-oligotrophication but across all lakes. The widespread increase in plankton richness coincided with widespread decrease in phosphate and total nitrogen concentrations, as well as with the trends in climate indicating a likely joint effect of nutrient reduction and climate in driving lake plankton. However, temporal changes and synchrony as well as the recovery of richness and composition of lake plankton more coherently corresponded with the nutrient loading reduction across the Danish landscape, while the role of climate control of the lake plankton was less pronounced.
\end{abstract}

Keywords: temporal coherence; zooplankton; phytoplankton; re-oligotrophication; lake recovery; lake restoration; plankton diversity 


\section{Introduction}

Eutrophication and climate change are the two major global stressors of freshwater lakes in recent decades. Eutrophication has been widely recognised as a serious problem due to the resulting notorious toxic algae blooms and low water clarity [1,2]. Consequently, various restoration measures have been implemented in different parts of the world, especially after the 1970s and 1980s [3-5]. At the same time, climate change has also been widely acknowledged as an important factor affecting freshwater ecosystems [6], especially due to the trends observed in lake physical characteristics [7]. Most importantly, climate warming is proposed to mimic and worsen the effects of eutrophication [8-10]. Therefore, understanding the extent and coherence of long-term ecosystem response to the changes in climate and eutrophication/re-oligotrophication is fundamental for lake conservation, restoration and management [11].

Effects of eutrophication have been widely documented in lakes. The most pronounced effects are increased phytoplankton biomass and associated degradation of water quality, as well as decreased diversity in lake plankton and changes in plankton community structure [12]. Reduction in nutrient concentrations produced by lake restoration efforts has also created marked responses in plankton biomass and community composition [5,13-16].

Long-term climate changes can also induce biotic and abiotic responses of lake ecosystems. For example, in the last decades, trends towards warmer lake water [17-20], changes in thermocline depth and delay in turnover [21] as well as alterations in lake-catchment interactions [22] have been documented. Furthermore, changes in plankton richness [23], phenology [24-26], community composition $[27,28]$ and trophic interactions $[29,30]$ have been recorded as a reaction to long-term warming.

Some studies have shown that nutrient changes have a stronger influence on lake plankton than long-term climatic alterations [31]. However, the response of plankton communities to nutrient reduction has sometimes been found to be weak or inconsistent in phytoplankton $[27,32,33]$ and zooplankton $[13,34,35]$. Therefore, a joint effect of changes in nutrient concentrations and climate is more likely [16,36]. Overall, the scarcity of long-term, multiple-lake data sets has limited our understanding of the combined effects of a changing climate and nutrient concentrations on the diversity of plankton and functioning of lake ecosystems [23,37,38].

Lake biotic and abiotic characteristics may have coherent temporal changes (i.e., synchrony) in several lakes sharing the same landscape indicating the driving role of large scale factors like climate or catchment-scale anthropogenic effects. Few studies have examined synchrony in temporal environmental and ecological changes among lakes [7,39-41]. Climatic effects, especially in the form of energy fluxes (i.e., temperature, irradiance), are uniform across large spatial scales and can induce synchronous changes in physical characteristics of lake water as well as, albeit weaker, in chemical and biological parameters [7,39,42]. Factors affecting the exchange of matter, especially mediated through the landscape, have been recognised to weaken the synchrony in biotic and abiotic lake variables across large spatial scales due to catchment-specific variations $[39,40]$. However, changes in matter exchange, mostly of anthropogenic origin, like acidification [43], eutrophication and re-oligotrophication [23,27], can also induce synchrony in lakes, even at large scales.

We analysed long-term trends in phyto- and zooplankton as well as lake water physico-chemistry and climate in 17 Danish lakes between 1989 and 2008. Many of the study lakes were recovering from previous eutrophication during the monitoring period [44]. We first tested if temporal changes in lake environmental and ecological characteristics were synchronous between lakes using mean pair-wise Pearson correlations across time series of each variable. Second, we assessed if variables demonstrated significant long-term trends during the study period using Kendall tests. In parallel, we also examined plankton community composition using Non-Metric Multidimensional Scaling (NMDS) and tested for directional temporal changes in plankton community composition during the study period. To better elucidate the effects of re-oligotrophication and to disentangle the role of climatic trends, we divided the lakes into three groups according to changes in their annual average TP concentrations, reflecting the strength of re-oligotrophication: lakes with a strong decline (S), lakes 
with weak changes $(\mathrm{W})$ and lakes with no change $(\mathrm{N})$. The analyses were performed for all lakes together and for each group separately as well as for the whole year (excluding winter) and each season separately (spring: months 3-5, summer: months 6-8 and autumn: months 9-11). We expected that strong re-oligotrophication indicated by a strong TP decrease would induce long-term trends and strong synchrony in the $\mathrm{S}$ lakes. Consistent trends in all lakes, especially in the $\mathrm{N}$ and W lakes, would indicate influence of other large-scale factors such as climatic effects.

\section{Materials and Methods}

Seventeen lakes were monitored (Figure A1) between 1989 and 2008 as part of the Danish monitoring programme on the aquatic environment [45]. Winter samples (December-February) were excluded due to varying sampling intensity across years. The remaining samples had an average sampling interval of 14 days (Table A1). Phytoplankton was collected from mid-lake depth-integrated samples covering the photic zone. Depth-integrated zooplankton samples were collected at three stations placed randomly in areas representing $80 \%$ of maximum depth and subsequently pooled. Phyto- and zooplankton were counted and their biomass was estimated based on size and shape. Details on plankton sampling, identification and counting can be found in Özkan, et al. [46]. All taxa were aggregated to genus level due to varying intensity of species-level identification between different plankton groups and potential differences in the identification skills of the taxonomists. We screened the plankton data for potential inconsistencies and made corrections with an inclusive approach [46].

Plankton biomass was calculated for the whole sample as well as for the main groups, i.e., Chlorophyta-CHL, Cyanobacteria-CYA, Bacillariophyceae-DIA, Cryptophyta-CRY, Chrysophyta-CHR and Euglenophyta-EUG for phytoplankton and Cladocera-CLA, Copepoda-COP and Rotifera-ROT for zooplankton. Additionally, the proportional biomass for all groups was calculated to estimate their contribution to total biomass (dominance). The proportional biomass excluding the three most dominant groups (CHL, CYA and DIA) was also calculated to examine the changes in the rare groups together. Genera richness, rarefied richness (based on biovolume for phytoplankton and on counting for zooplankton) and Pielou's evenness [47] were calculated as surrogates of plankton diversity. Richness of the main groups of plankton was also calculated.

Samples for the analysis of lake water chemistry were collected simultaneously with the zooplankton samples and analysed for total phosphorus (TP), phosphate $\left(\mathrm{PO}_{4}\right)$, total nitrogen (TN), nitrate+nitrite $\left(\mathrm{NO}_{3-2}\right)$, ammonia $\left(\mathrm{NH}_{4}\right)$, silicate $\left(\mathrm{SiO}_{2}\right)$, chlorophyll-a (Chl-a), suspended solids (SS), $\mathrm{pH}$ and alkalinity $[45,48]$. Temperature in the water column was recorded at one-metre intervals at the deepest point of the lake. Water column stratification was calculated from temperature profiles as Schmidt stability index [49]. Matlab codes from Lake Analyser software [50] were adapted in $\mathrm{R}$ environment for the Schmidt stability index calculations. Calculations were made only when temperature was recorded at least to the mid-depth of the lake, and the temperature profile was forced to be monotonic from bottom to top before calculations. When a lake variable was missing for a sample, it was replaced by the most relevant available data: first, the mean of observations in a seven-day temporal window; second (if a substitute sample was not available at the first step), the mean of observations in a 15-day window or, third, linear interpolation of neighbouring samples if they were less than 30 days apart (Table A1).

Mean air temperature, wind speed, solar irradiance (from daily averages interpolated to $20 \mathrm{~km}$ grids) and precipitation (from daily averages interpolated to $10 \mathrm{~km}$ grids and corrected for wind and altitude depending on the month of the year) were compiled from the Danish Meteorological Institute. Main characteristics of the lakes are given in Table 1.

Table 1. Summary of lake morphology and nutrient concentrations in the study lakes.

\begin{tabular}{cccccc}
\hline & Lake Area (ha) & Average Depth $(\mathbf{m})$ & Max. Depth $(\mathbf{m})$ & TP $\left(\mathbf{m g} \cdot \mathbf{L}^{-\mathbf{1}}\right)$ & $\mathbf{T N}\left(\mathbf{m g} \cdot \mathbf{L}^{-\mathbf{1}}\right)$ \\
\hline Min. & 12 & 0.8 & 1.8 & $<0.001$ & 0.100 \\
Median & 37 & 2.7 & 6.0 & 0.075 & 1.770 \\
Max. & 3954 & 15.1 & 32.6 & 2.700 & 19.000 \\
\hline
\end{tabular}


Many of the study lakes have been subject to re-oligotrophication during the monitoring period following earlier eutrophication. We expected that the strength of the nutrient decline is the prominent determinant of the trends in plankton. Therefore, we classified the lakes into three groups according to trends in TP concentration, reflecting the strength of re-oligotrophication (Figure 1): strong decline, weak decline and no decline lakes. The trends were assessed using Mann-Kendall rank correlation [51]. Comparison of the analyses across these lake groups enabled us to better understand the effect of re-oligotrophication and to disentangle the role of climatic trends. Six lakes experienced a significant and substantial decrease in TP with overall high TP concentrations (Tau $>0.2$, annual mean TP $0.59-0.14 \mathrm{mg} \cdot \mathrm{L}^{-1}$ ) and were grouped as S (strong TP decrease) lakes. Six lakes had significant but weak changes at moderate-high TP concentrations (Tau $< \pm 0.2$, annual mean TP $0.40-0.05 \mathrm{mg} \cdot \mathrm{L}^{-1}$ ) and were grouped as W lakes (weak TP decrease). Three lakes with low TP concentrations (annual mean TP $<0.03 \mathrm{mg} \cdot \mathrm{L}^{-1}$ ) exhibited no trend in TP and were grouped as N (no TP decrease) lakes. The statistical analyses of synchrony in temporal changes, long-term temporal trends and community changes were performed and reported for all lakes and each group separately. Two lakes also experienced a significant decrease in TP with Tau $>0.2$; however, the change occurred across a short TP gradient with overall low concentrations (annual mean TP $0.03-0.02 \mathrm{mg} \cdot \mathrm{L}^{-1}$ ). Therefore, these two lakes were not assigned to any group, but included in the analyses when the lakes were analysed or reported together.

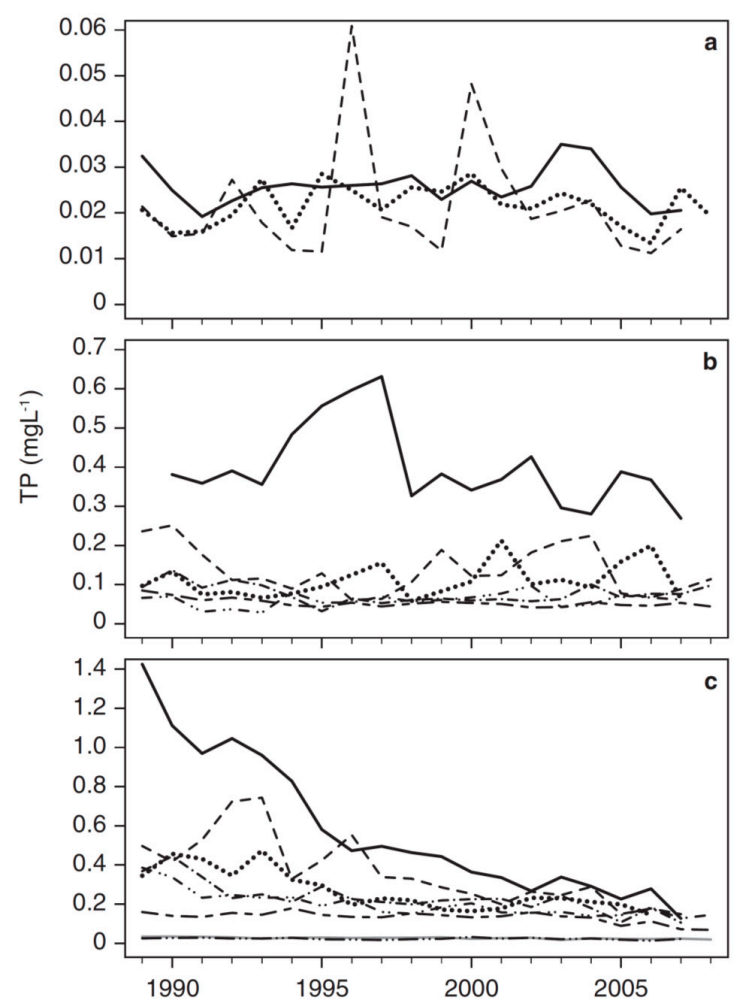

Figure 1. Annual mean total phosphorus (TP) change in lakes with no TP trend (N lakes, a), with a weak decreasing TP trend (W lakes, b) and with a strong TP decrease (S lakes, c). Two lakes at the bottom of the c plot were not included in the $S$ lake category due to very low TP concentrations. Note that the range of the $y$ axes are different between the plots.

We assessed if temporal changes in climatic, lake physico-chemical and plankton variables occurred synchronously across lakes, reflecting common large-scale driving factors (for example climate). Annual and seasonal means were calculated for each climatic, physico-chemical and plankton variable in each lake. This provided an annual time series for each variable in each lake. Each time series was standardised to zero mean and unit standard deviation prior to the analyses. The synchrony 
of a variable was calculated as mean pair-wise Pearson correlation coefficient (r) for all pairs of time series of that variable across lakes [7].

We quantified the strength and significance of long-term changes in each variable in each lake by testing for monotonic trends in each variable over the two decades using Mann-Kendall rank correlation [51]. The Kendall correlation coefficient (Tau) was taken as zero when the test was insignificant. We expected a monotonic fit to be adequate as two main drivers of these ecosystems, nutrient levels and climate, had monotonic changes during the study period. The majority of the lakes had experienced nutrient reduction due to restoration [52], and no shift was observed in the decreasing trend in the NAO index (Figure 2) during the study period.
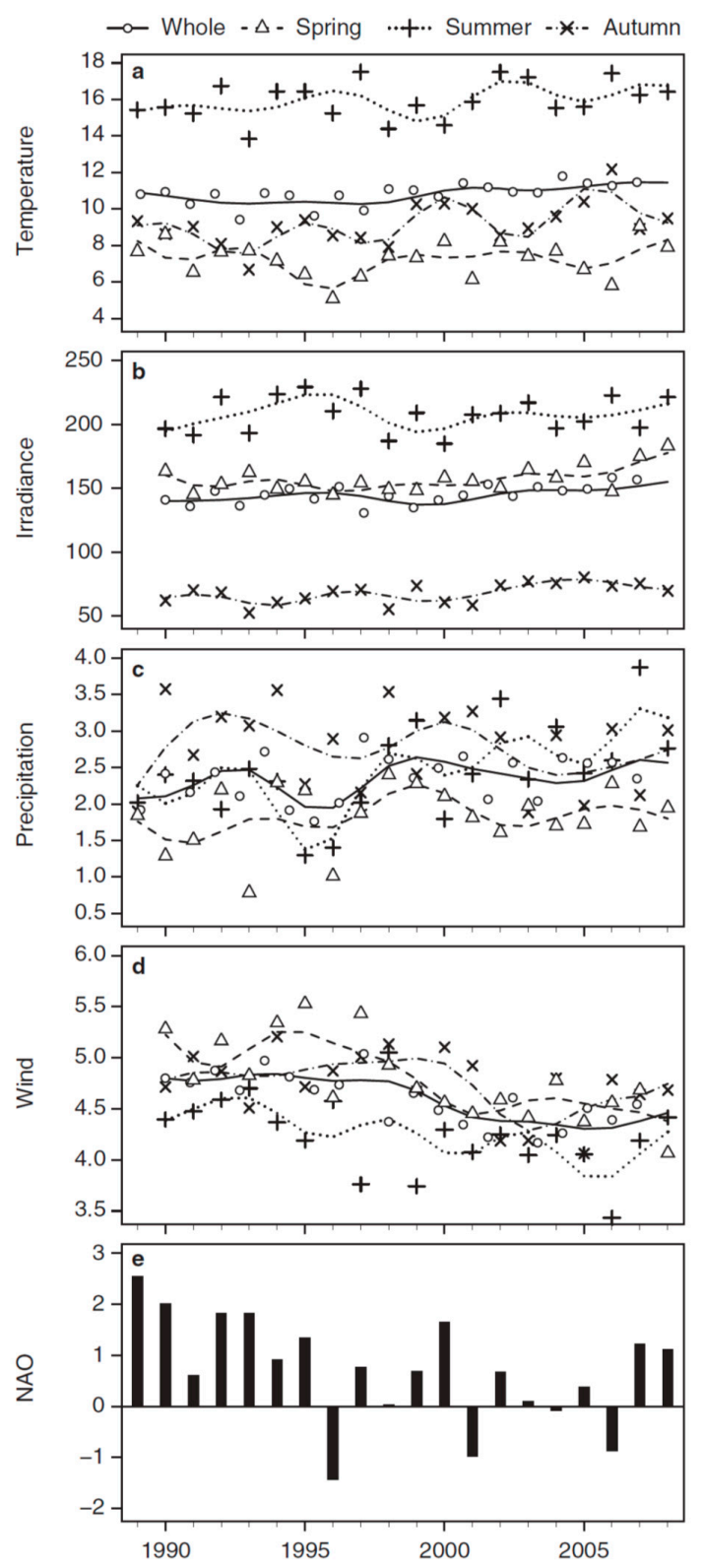

Figure 2. Two-decade trends in temperature $\left(\mathbf{a},{ }^{\circ} \mathrm{C}\right)$, solar irradiation $\left(\mathbf{b}, \mathrm{W} \cdot \mathrm{m}^{-2}\right)$, precipitation $(\mathbf{c}, \mathrm{mm})$ and wind speed $\left(\mathbf{d}, \mathrm{m} \cdot \mathrm{s}^{-1}\right)$ averaged over 17 lakes, as well as the North Atlantic Oscillation Index (e). Yearly means were calculated for the whole year excluding winter and separately for spring, summer and autumn. Generalised additive model annual smoothers [53] were overlaid to each dataset to summarise trends $(P<0.05$ for all). 
We examined how phyto- and zooplankton community composition changed in the study lakes during the study period using NMDS ordinations [54]. In each lake, the plankton community is defined annually as pooled plankton communities. The pooling is performed as summed taxa biomass. All plankton lake-years were ordinated together separately for phyto- and zooplankton. These ordinations were examined to understand if there are any directional changes in a lake and if these changes are similar across lakes, depicting the roles of nutrient reduction and climate change. The analyses were also undertaken for seasonally pooled plankton communities. The number of plankton samples in a lake for the whole year and each season varied during the study period. To assemble a balanced dataset for ordinations, 14, 3, 4 and 3 plankton samples were pooled as annual, and seasonal (spring, summer and autumn, respectively) plankton communities for each lake and year. Lake years without sufficient samples were omitted from the analyses and a random selection was made for lake years with an excess number of samples.

Ordinations were performed for two axes (as the plankton community space is to be represented in two dimensions in the analyses) based on Bray-Curtis distances between pair-wise plankton communities. The stress values were sub-optimal $(0.27$ and 0.24 for phytoplankton and zooplankton ordinations, respectively) as we tried to ordinate in two dimensions. Most of the models did not converge and we therefore used the best solution after 1000 trials. However, the conclusions were identical for several different trials (visually checked).

Each lake was analysed to see if the plankton communities showed significant directional changes in the ordination space. The axis scores were modelled against years using multivariate linear modelling, and significance was tested using the ANOVA function. If a significant change emerged in a lake, the direction of change was plotted with a vector. End points of the vector corresponds to the predicted axis scores for the start and end years in that lake. If there is no significant change in a lake, an ellipse centred on mean axis scores of sites is plotted with radiuses corresponding to the maximum distance of sites from the mean for each axis.

All analyses were performed for all lakes combined and separately for each group of lakes as well as for time-series for the whole year (excluding winter) and separately for each season. Seasons were defined as months 3-5, 6-8 and 9-11 for spring, summer and autumn, respectively. Statistical analyses were made using R [55] with the vegan package [56] for NMDS ordination, the Kendall package [57] for monotonic trend analyses in time series and the mgcv package [53] for Generalized Additive Model smoothers.

\section{Results}

\subsection{Synchrony in Temporal Changes}

Climate variables exhibited strong synchrony in temporal trends (c. $\mathrm{r}>0.7)$ for all lakes combined (Figure 3). The patterns of synchrony in climatic variables were similar in each $\mathrm{S}, \mathrm{W}$ and $\mathrm{N}$ lake groups (Figure 3). The synchrony was less marked for wind and precipitation than for air temperature and irradiance. Lake water variables had weaker synchrony than climatic variables; however, surface water temperature demonstrated consistent moderate synchrony $(c . r=0.5)$ in all lakes and in the different lake groups. Synchrony in water column stability was weaker than that of water temperature and varied between lake groups, likely reflecting an uneven distribution of deep and shallow lakes across lake groups. Lake chemistry variables with significant synchrony in all lakes mostly consisted of nutrient variables ( $\mathrm{TN}, \mathrm{NO}_{3-2} \mathrm{TP}, \mathrm{PO}_{4}$ ), and their synchrony was three-fold weaker than that of climate variables. The patterns of synchrony in water chemistry variables differed considerably among lake groups. $S$ lakes had significant synchrony for a large set of water chemistry variables dominated by several nutrient variables, and the strength of the synchrony in TN and TP was as large as that of the climatic variables (c. $r>0.6$ ). Furthermore, SS and Secchi disk depth reflecting water clarity also exhibited moderate synchrony in $S$ lakes $(r=0.3-0.5)$. However, few variables showed a weak to moderate synchrony in $\mathrm{W}$ and $\mathrm{N}$ lakes. 


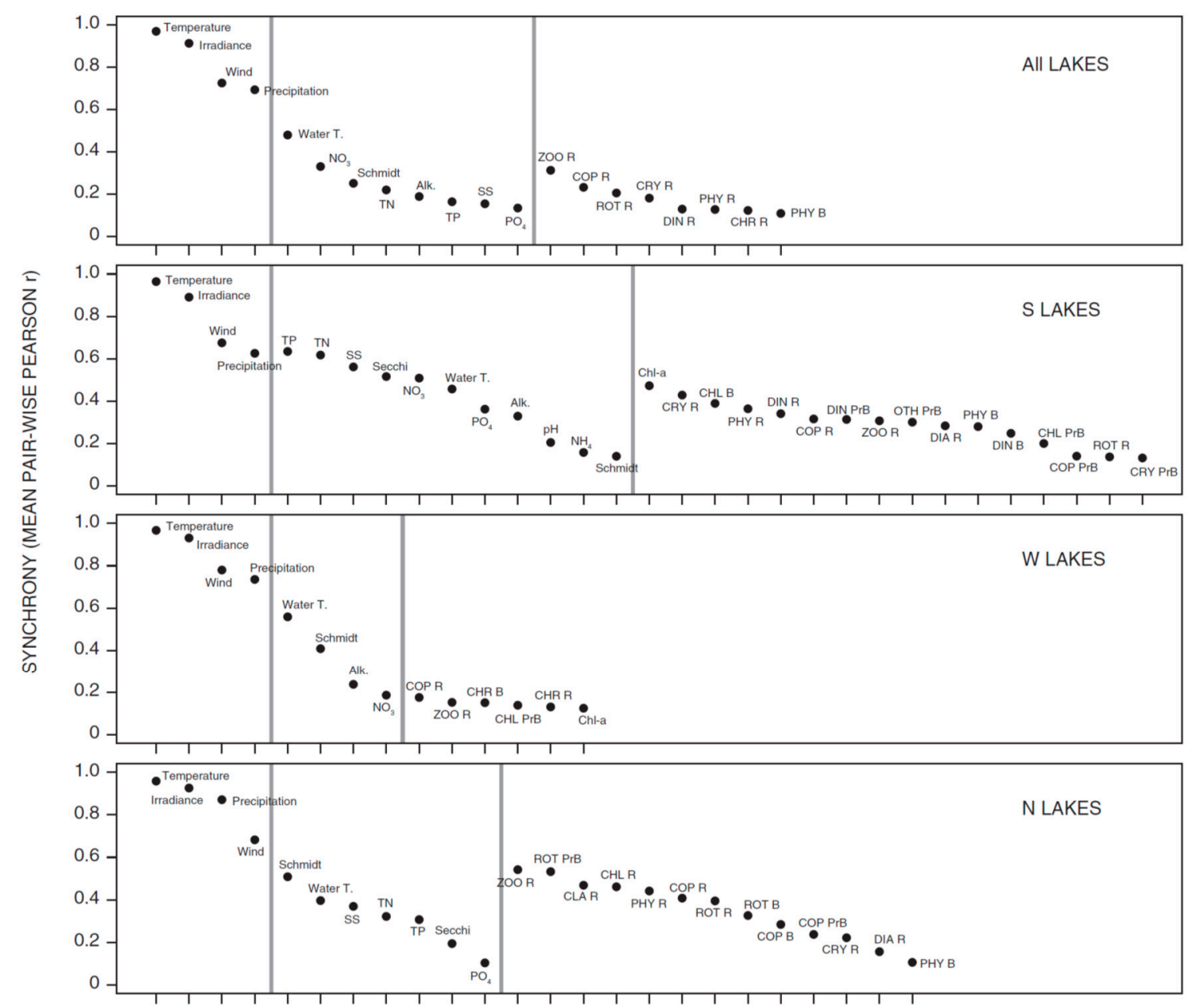

Figure 3. Summary of the synchrony in climate, lake physico-chemistry and plankton variables for the whole year excluding winter analysed for all lakes and for the $\mathrm{S}, \mathrm{W}$ and $\mathrm{N}$ lakes separately. $Y$ axis represents synchrony calculated as mean pairwise correlation of each variable. Only variables with $r>0.1$ are given and main variable groups are divided by vertical lines as climate, lake water characteristics and plankton variables. Results of separate analyses for each season are given in the Figures A2-A4.

The pattern of synchrony in plankton variables largely reflected the pattern of synchrony in lake chemistry in all lake groups. Notably, a moderate synchrony was observed for the richness of several plankton groups in all lakes and in each lake group. There was also synchrony in the richness of all and of the main groups of zooplankton as well as in the richness of all and some groups of phytoplankton and in phytoplankton biomass.

A large number of plankton variables exhibited moderate synchrony in $S$ lakes $(<0.6)$, and synchrony was generally stronger for phytoplankton biomass and richness variables than for other plankton variables. $\mathrm{N}$ lakes also demonstrated moderate synchrony for a large number of plankton variables; yet, in contrast to the $S$ lakes, synchrony was stronger for variables related to zooplankton richness than for other plankton variables. However, only a few plankton variables showed synchrony in W lakes, and only weakly so.

The analyses of synchrony were repeated for each season (Figures A2-A4). The strength of synchrony in climatic variables was similar across seasons. Synchrony in surface temperature and water column stratification was stronger in summer than in the other seasons. Weaker synchrony was observed in lake chemistry and plankton variables in summer and autumn than in spring in all 
lakes, this being true also for the $\mathrm{W}$ and $\mathrm{N}$ lakes. However, synchrony in lake chemistry and plankton variables in $\mathrm{S}$ lakes was generally consistent across seasons.

\subsection{Long-Term Trends in Environmental and Plankton Variables}

Climatic parameters exhibited significant, but weak long-term monotonic trends over the two decades (Table A2, Figure 2 and Figure A5). Air temperature had a significant positive trend for the whole year (excluding winter) and for each season separately $(\mathrm{r}=0.05-0.09, P<0.01$ ), with the strongest trend observed in summer. Wind speed demonstrated a significant negative trend for the whole year and for each season $(\mathrm{r}=-0.05--0.10, P<0.01)$; the strongest trend occurring in spring. Precipitation showed a significant positive trend for the whole year and in summer $(r=0.02$ and 0.05 , $P<0.05)$. Irradiance had a significant positive trend only in spring $(r=0.07, P<0.001)$. These trends coincided with a decrease in the NAO index (Figure 2). The trends in temperature, irradiance and precipitation were uniform across lakes (Figure A5). Only the trends in wind speed exhibited variation across lakes (Figure A5).

No significant long-term trend was detected in water column stability and surface temperature in the study lakes, when analysed for the whole year (Figure 4). However, strong long-term trends were observed in the annual time series of several lake chemical variables, especially a widespread decrease in $\mathrm{N}$ and $\mathrm{P}$ concentrations is observed (Figure 4). Notably, TN demonstrated a decreasing trend in all, but two $\mathrm{W}$ lakes and $\mathrm{PO}_{4}$ generally had a decreasing trend except in three lakes (Figure 4). $\mathrm{NO}_{3-2}$ decreased in all $\mathrm{W}$, two $\mathrm{N}$ and two $\mathrm{S}$ lakes. $\mathrm{NH}_{4}, \mathrm{SiO}_{2}$ and $\mathrm{pH}$ showed no clear trend across the different lake groups; however, $\mathrm{pH}$ decreased for three $\mathrm{S}$ lakes. Alkalinity and Secchi depth increased and SS decreased in all S lakes. Overall, the decreasing trends in nutrient concentrations and the increasing trends in water clarity were pronounced in the $S$ lakes. In the analyses of seasonal time series (Figures A6-A8), surface temperature exhibited a positive trend in $70 \%$ of the lakes in summer. The main patterns were similar between seasons for the remaining lake chemistry variables, however, the nutrient reduction was strongest in spring in all lakes. The negative trend in TP and $\mathrm{PO}_{4}$ was slightly weaker, while the increase in Secchi disk and decrease in SS were stronger in the S lakes, in summer than in the other lake groups.

The annual time series of plankton richness and biomass variables also exhibited strong long-term trends that reflected the patterns in lake physico-chemical variables (Figure 4). Generally, the trends in phytoplankton variables were more pronounced in the S lakes, whereas the zooplankton trends were similar across all lakes. Total phytoplankton biomass and Chl-a strongly decreased in all S lakes except for one, with only few inconsistent significant trends in the $\mathrm{W}$ and $\mathrm{N}$ lakes. Phytoplankton richness increased for all $\mathrm{S}$ and $\mathrm{N}$ lakes, albeit more strongly in the former. Notwithstanding the increases found in three $\mathrm{S}$ lakes, no clear patterns emerged for phytoplankton evenness. Zooplankton biomass did not show clear differences among lake groups, whereas zooplankton richness increased in all but two lakes, whilst evenness decreased in $65 \%$ of the lakes. Richness of all the main groups of phytoplankton, except CYA and CHR, increased in the $S$ lakes. CHL richness increased in all $\mathrm{N}$ lakes, while CRY richness increased in all, but two $\mathrm{W}$ lakes and one $\mathrm{N}$ lake. Both CHL biomass and dominance decreased in the $\mathrm{S}$ lakes, while the total contribution of all rare groups as well as the biomass of DIN, CRY and EUG increased. In contrast, CYA dominance increased in four S lakes. Richness of all the main groups of zooplankton increased in $90 \%$ of the lakes, without any pattern in biomass. However, CLA dominance increased in six lakes, with a decrease in only one lake, while ROT dominance decreased in all N lakes. Seasonally (Figures A6-A8), the negative trend in phytoplankton biomass was strongest in spring, while the positive trend in phytoplankton richness and the negative trend in Chl-a were strongest in summer in the S lakes.

The generally increasing trend in plankton richness also appeared in the annually pooled plankton communities (Figure 5). Phyto- and zooplankton richness of pooled communities correlated positively with year in $40 \%$ and $75 \%$ of the lakes, respectively. 

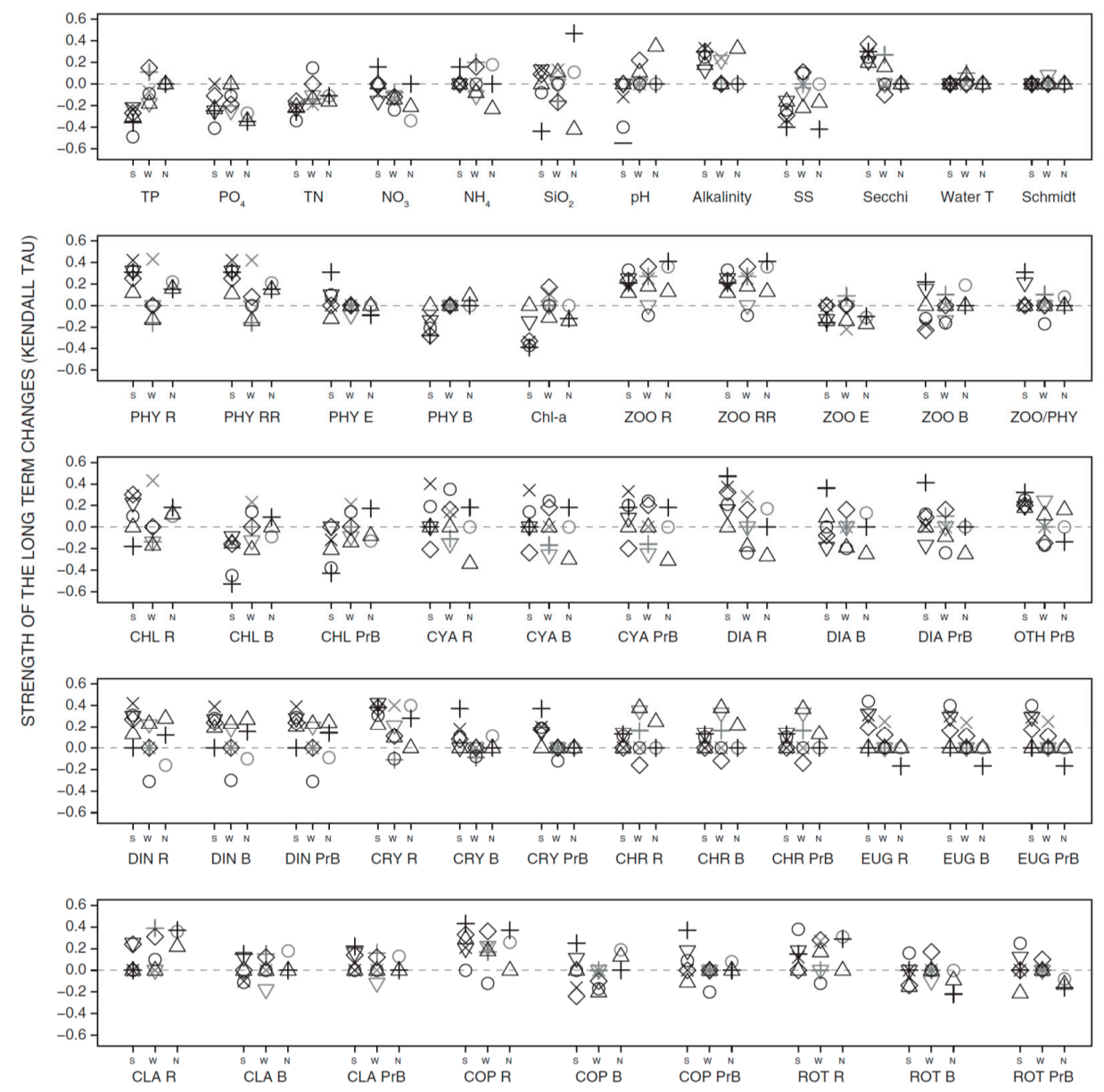

Figure 4. Summary of the monotonic long-term trends in lake physico-chemical and plankton variables. Trends were analysed using Kendall correlations and the magnitude of the temporal correlation was reported in $Y$ axis in each panel. Lakes were grouped into $\mathrm{S}, \mathrm{W}$ and $\mathrm{N}$ lakes. Plotting symbols represent a unique lake in each lake group for different variables, and grey colour represents deep lakes (mean depth $<3.5 \mathrm{~m}$ ). The Kendall correlation is taken as 0 for the insignificant tests. R, richness; RR, rarefied richness; E, evenness; B, biomass; $\mathrm{PrB}$, proportional biomass; CHL, Chlorophyta; CYA, Cyanobacteria; DIA, Bacillariophyceae; OTH, all phytoplankton groups excluding CHL, CYA, DIA; CRY, Cryptophyta; CHR, Chrysophyta; EUG, Euglenophyta; CLA, Cladocera; COP, Copepoda; ROT, Rotifera. Results of separate analyses for each season are given in the Figures A6-A8.

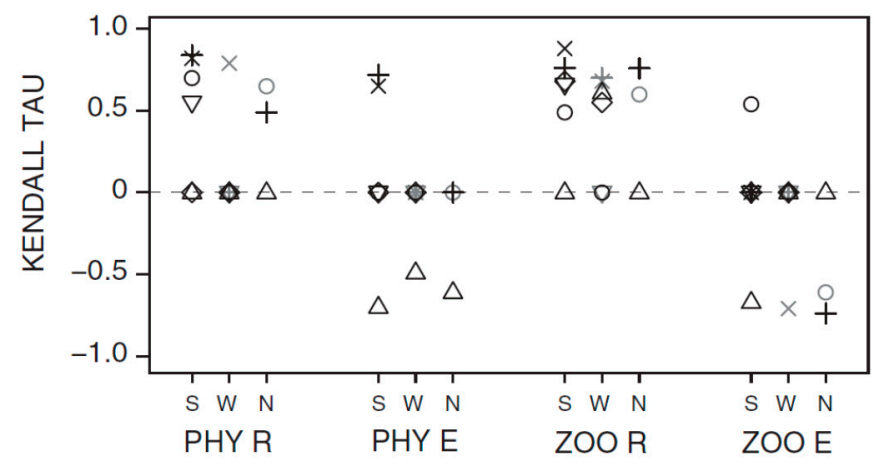

Figure 5. Summary of temporal change (Pearson's correlation with years) in annual phyto- and zooplankton assemblage richness and evenness in S, W and N lakes. See Figure 4 for details. 


\subsection{Long-Term Trends in Plankton Community Composition}

When analysed with NMDS, phytoplankton communities differed strongly between S, W and $\mathrm{N}$ lakes (Figure 6), with a gradient from CHL and CYA dominance in the S lakes towards more heterogeneous communities in the $\mathrm{N}$ lakes. Phytoplankton communities of most $\mathrm{S}$ lakes showed a significant temporal trend in their community composition towards that of the $\mathrm{N}$ lakes, being consistent across all seasons. Only a few $\mathrm{W}$ lakes had a significant directional temporal trend, and the direction was not consistent. Zooplankton community composition also differed between $\mathrm{S}, \mathrm{W}$ and $\mathrm{N}$ lakes (Figure 7) with a gradient from ROT and COP dominance in S lakes towards more heterogeneous communities with increasing CLA contribution in the $\mathrm{N}$ lakes. However, the temporal change in zooplankton composition was weaker and less consistent in direction than that of phytoplankton.
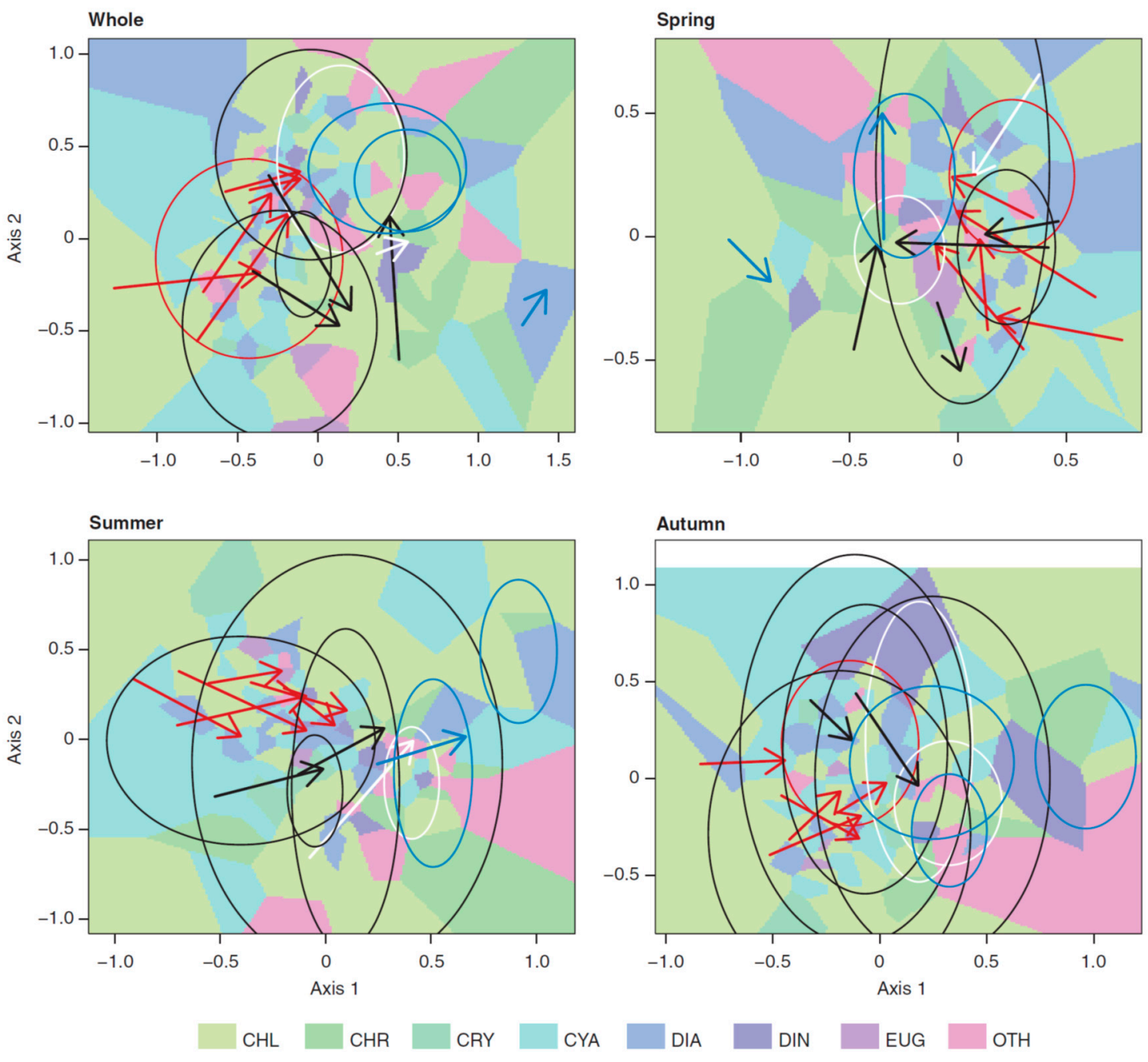

Figure 6. Non-Metric Multidimensional Scaling (NMDS) ordination of annual and seasonal phytoplankton assemblages. Following the ordinations taxa scores were aggregated for main groups, and Voronoi polygons were plotted for each main group. The legend explaining which colour represents which phytoplankton group was given below the figure. The colours in the background represent the compositional surface of the phytoplankton assemblages in all lakes. Temporal change in assemblage composition is displayed by an arrow for lakes with significant change between years. Compositional variation in lakes without significant change is indicated with an ellipse. Blue, black and red are used for N, W and S lakes, respectively, for the arrows and ellipses. Two lakes not included in any of the groups are indicated with white. For details see Figure 4. 

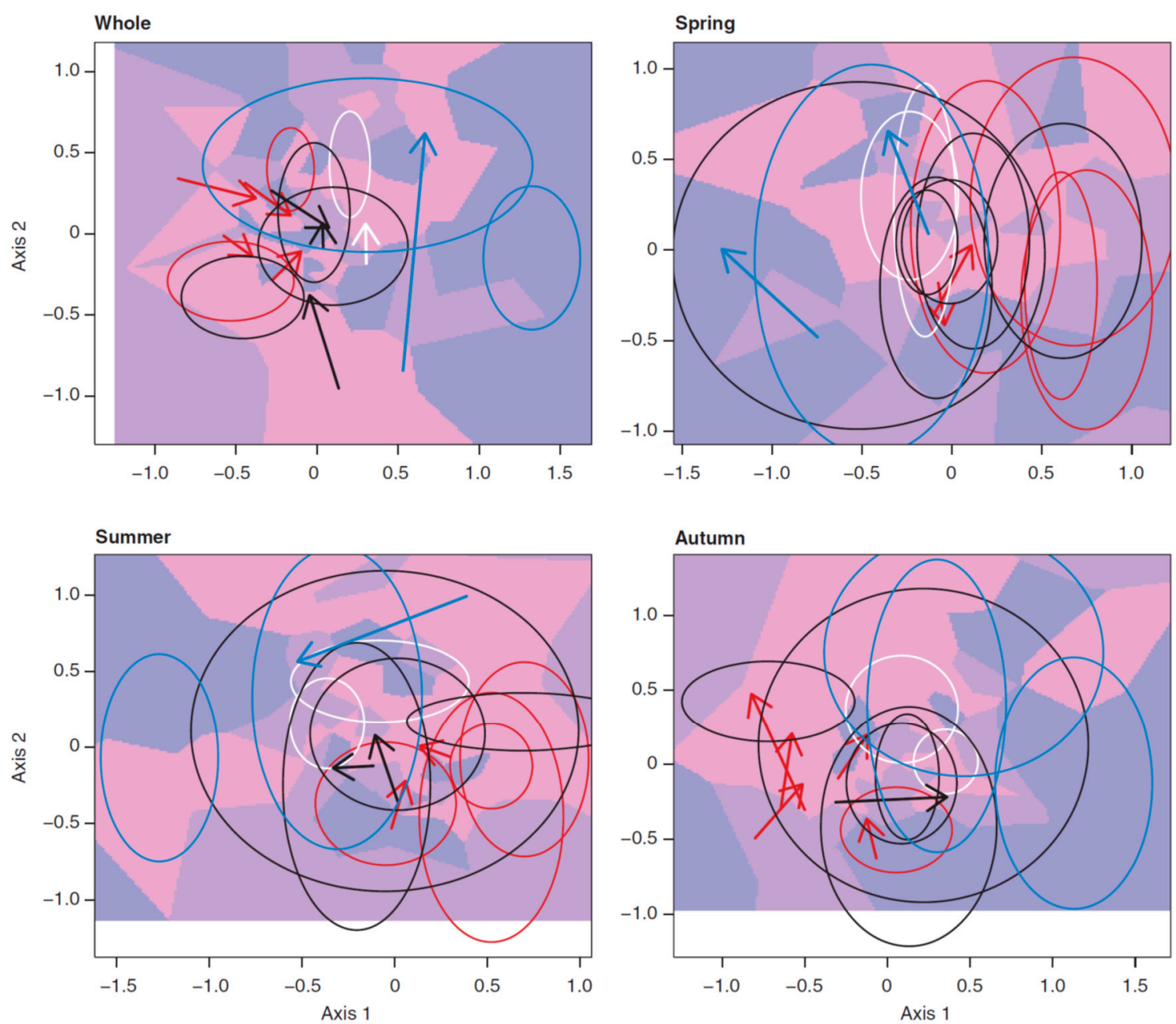

CLA $\quad$ COP $\quad$ ROT

Figure 7. NMDS ordination of annual and seasonal zooplankton assemblages. See Figures 4 and 6 for details.

\section{Discussion}

Analyses of two-decade time series of 17 Danish lakes revealed synchronous temporal changes in biotic and abiotic lake characteristics and several significant long-term trends in lake plankton, which were most consistently associated with a widespread decline in nutrient concentrations. The temporal trends indicated that the restoration measures implemented in the Danish lakes have led to improved water quality and recovery of plankton communities in most of the study lakes, potentially creating a widespread increase in plankton richness.

The temporal trends in the studied variables showed the strongest synchrony for climatic variables and for the lake characteristics most influenced by these such as surface water temperature and water column stability. The strong synchrony in climate variables across Danish lakes was to be expected due to the lack of altitudinal differences and the spatial scale of the study $(<300 \mathrm{~km})$. Wind speed and precipitation had weaker synchrony (c. 0.7$)$ and more variability among lakes than temperature and solar irradiance (c. 0.9), reflecting that wind and precipitation are more affected by local factors $[7,40]$. The synchrony in air temperature induced a corresponding synchrony in surface water temperature and water column stratification, these having a direct link to climate and thus a stronger synchrony than lake chemistry [7]. The positive albeit weak long-term trend in air temperature and negative trend in wind speed did not translate into a long-term trend in surface water temperature and stratification in the whole-year time series, and no clear effect of annual changes in climate on lake chemistry was 
identified. Only in summer, when the positive long-term trend in temperature was strongest, did a corresponding significant positive trend in surface water temperature occur. This suggests that either the climatic changes were not strong enough to induce a trend in lake water, except for summer, or that the effect of these variables was confounded by catchment-specific factors. An analysis of 125 freshwater and marine phytoplankton time series demonstrated that climate-driven phytoplankton biomass cycles were heavily obscured by other drivers of population variability, indicating the difficulty of detecting climate-driven trends in plankton communities [58]. However, a long-term warming trend has been documented for both North American [17,18] and European $[19,20]$ deep lakes in investigations covering a longer time period than in our study. Deep dimictic lakes with stable summer stratification are known to better reflect long-term climatic trends, whereas frequently circulating polymictic lakes are least influenced [59]. Therefore, the lack of a strong link between the long-term trends in climate and lake physico-chemistry may reflect that most of the lakes in the present study were polymictic shallow lakes and that only a weak change in annual mean air temperature occurred in the period covered by our study. However, analyses at seasonal and short-term scales may also demonstrate stronger climatic control, for instance, through extreme weather events [60], changes in the duration, frequency and depth of stratification [61] and the spring phenology of plankton $[24,36,62]$. For example, in analyses of 20 Danish lakes some of which are included in the present study found a decrease in the depth of the thermocline with a delay in autumn turnover in response to climate change [21].

The annual means of water chemistry variables were also synchronous across lakes, though with a three-fold decrease in strength in comparison with climate variables. Weaker synchrony in lake chemistry than in climate reflects a confounding influence of catchment-scale local factors or internal dynamics $[7,40]$. A more widespread and stronger synchrony in water chemistry and water clarity in the $S$ lakes indicated that the strong nutrient reduction in these lakes played an overriding role in the temporal trends. This suggests that the steep environmental gradients had a stronger effect in lake ecosystems than the climatic changes in the two-decades the study period. Furthermore, long-term decreasing trends in $\mathrm{PO}_{4}, \mathrm{TN}$ and $\mathrm{NO}_{3-2}$ in most of the lakes $(80 \%, 90 \%$ and $75 \%$, respectively) accompanied by a moderate synchrony in $\mathrm{NO}_{3-2}, \mathrm{TN}, \mathrm{TP}$ and $\mathrm{PO}_{4}$, reflected marked nutrient reduction in all studied Danish lakes, not only in $\mathrm{S}$ lakes [5]. The significant decrease in nutrients is consistent with the fact that the Danish landscape is largely used for agricultural activities (c. 60\%, [63]), and a recent reduction in fertilizer use and changes in agricultural activities have resulted in decreased nutrient loads from lake catchments $[64,65]$. The analysis of long-term trends in N:P ratio (Figure A9) showed that $\mathrm{N}: \mathrm{P}$ ratio increased in three $\mathrm{S}$ and two $\mathrm{W}$ lakes reflecting the decrease in TP concentrations. Whereas, N:P ratio decreased in all $\mathrm{N}$ lakes and two $\mathrm{W}$ lakes probably indicating that the reduced $\mathrm{N}$ input from the lake catchments resulted in a decrease in N:P ratio in the absence strong decline in $\mathrm{P}$ concentrations. However, reduced phosphorus concentrations in lakes have been proposed to lead to a decrease in $\mathrm{N}$ removal efficiency [66]. An analysis of long-term time series for 12 deep lakes showed a marked increase in $\mathrm{N}$ concentrations following a sharp decrease in $\mathrm{P}$ concentrations, despite stable or decreasing $\mathrm{N}$ inputs [66]. In the present study, however, both $\mathrm{N}$ and $\mathrm{P}$ concentrations exhibited a widespread long-term decrease. The co-decrease in $\mathrm{N}$ and $\mathrm{P}$ was most likely due to successful management of both point and non-point nutrient sources in Danish catchments $[64,65]$ rather than internal dynamics subsequently resulting in potential $\mathrm{N}$ accumulation [66]. Furthermore, the majority of the lakes in the present study were shallow and small with short residence times, which might have facilitated stronger $\mathrm{N}$ removal $[5,67]$.

Previous studies suggest that lake biotic variables are less synchronous than abiotic variables $[7,39,40,68,69]$. Here plankton displayed a weaker annual synchrony than climate. However, the strength of the synchrony in plankton was at a similar level as that of lake chemistry, probably indicating primary control of the temporal changes in lake plankton by lake chemistry. The strong re-oligotrophication in the $\mathrm{S}$ lakes resulted in high levels of synchrony in lake water chemistry and plankton. The re-oligotrophication in S lakes also resulted in strong and consistent long-term water 
quality improvements with a decrease in phytoplankton biomass and a shift from Chlorophyta dominance towards more heterogeneous and richer phytoplankton communities. The weaker synchrony and less consistent long-term trends in the $\mathrm{W}$ and $\mathrm{N}$ lakes indicate that confounding catchment-scale processes or internal lake dynamics weaken the synchrony in temporal changes in lake chemistry and plankton when loading reduction is not substantial $[7,39,40]$. Overall, the variation across lake groups indicated that the synchrony and long-term trends in lake plankton were predominantly controlled by the strength of re-oligotrophication. Analyses conducted in the earlier phase of the monitoring programme revealed that 10 lakes, experiencing nutrient reduction prior to 1999, responded immediately in the form of decreasing Chl-a concentrations [52]. A decrease in phytoplankton biomass and a shift towards a phytoplankton community more associated with oligotrophic conditions in response to nutrient reduction have been widely documented $[5,13,14]$. However, a weak or inconsistent response of phytoplankton biomass and community composition to nutrient reduction has also been observed [27,32,33]. Although a strong decline in TP and phytoplankton biomass is expected to lead to a corresponding decline in zooplankton biomass [13,34], no such response was observed in the $S$ lakes, which corroborates previous observations [35]. Earlier analyses of Danish lakes in recovery from eutrophication have also revealed a weak or insignificant response of zooplankton biomass to re-oligotrophication, suggesting changes also in top-down effects [52,70,71]. Furthermore, a paleolimnological study conducted in Switzerland in three deep lakes covering the past 70-150 years of climate change found that the response of zooplankton to climate change was largely regulated by local changes in nutrient inputs and fisheries [72]. Specifically, the analyses showed that climate had a very limited effect on the cladoceran community in Lake Annecy, the most nutrient limited lake, whereas Lakes Geneva and Bourget with higher nutrient concentrations were more sensitive to climate warming in the past 70-150 years [72].

Notably, the richness of phyto- and zooplankton, as well as that of many of their main groups, exhibited synchrony and increasing long-term trends in all lakes. Furthermore, the richness of annually-pooled phyto- and zooplankton communities increased across years for most of the lakes. The widespread and synchronous increase in plankton richness coincided with the synchronous negative trends in $\mathrm{PO}_{4}, \mathrm{TN}$ and $\mathrm{NO}_{3-2}$ revealed in most of the lakes as well as the positive trends in temperature and precipitation, and the negative trend for wind speed. As the trends in climate and nutrients co-occurred and were mostly monotonic without a shift during the study period, it was not possible to perform a conclusive hypothesis test to elucidate which of these trends was responsible for the widespread increase in plankton. However, the overall patterns in long-term temporal trends and synchrony in the lake chemistry and plankton variables provided more consistent support for the dominant role of nutrient reduction in driving the plankton richness increase.

The widespread nutrient reduction [73] in most of the lakes included in the Danish monitoring programme may potentially have a positive effect on plankton richness. $\mathrm{N}$ and $\mathrm{P}$ have been recognised as co-limiting factors of plankton abundance in shallow lake ecosystems [74-76] and they are thus significantly related to the diversity of phytoplankton [77] and submerged macrophytes [76]. Therefore, the observed nutrient reduction in the study lakes might have increased phytoplankton richness by releasing the competitive pressure [78]; this, in turn, may have enhanced the zooplankton richness by allowing niche partitioning [46,79-81]. Analyses of 30 years' data on Lake Zurich also demonstrated a strong association of phytoplankton and zooplankton richness, pointing at the role of food web interactions in sustaining diversity across trophic levels [23]. Chl-a declined and Secchi depth increased in several lakes (most pronounced in the S lakes) with a widespread long-term decrease in SS. This was probably indicative of water quality improvements, which might have promoted submerged macrophyte growth. The potential recovery of submerged macrophytes may also contributed to the increase in planktonic diversity [82-85].

Changes in the identification efficiency of taxonomists over time may potentially confound the suggested increase in plankton richness, especially in long-term datasets $[33,86]$. Yet, the increasing trend for most of the plankton groups included in the present study was consistent, including Cladocera 
for genus level identification presents no difficulty. Climatic trends, especially changes in temperature and wind may also affect plankton richness [23], phytoplankton phenology [24-26] and community composition $[27,28]$. The effects of extreme climate events on plankton ecology have also been recorded [23]. However, the direct effect of air temperature on surface water temperature was limited and only significant in summer. Also, no trend in stratification and no clear and consistent effect of climatic trends on plankton were found in the present study. In addition, previous studies have shown that nutrient changes may have a stronger influence on lake plankton than long-term climatic trends [31]. Nonetheless, a joint effect of nutrient reduction and climate in driving an increase in both the taxonomic and the functional richness of phytoplankton is perhaps more likely $[16,23]$. Overall, although a conclusive test was not possible, the widespread nutrient reduction in Danish lakes were most consistently associated with the trends in plankton, and thus it might have been the dominant factor behind the temporal increase in plankton richness.

The pattern in synchrony and long-term trends varied when the analyses were conducted separately for each season. Synchrony in water chemistry as well as long-term nutrient reduction, Secchi depth improvement and phytoplankton biomass decrease were strongest in spring, while the increase in plankton richness was strongest in summer in all the lakes. In the $S$ lakes, synchrony was consistent across seasons, reflecting the overriding effect of strong re-oligotrophication. The negative trends in $\mathrm{TP}$ and $\mathrm{PO}_{4}$ in the $\mathrm{S}$ lakes were slightly weaker in summer, which has also been observed in previous analyses of Danish [87,88], British and German lakes [13,34] and may be attributed to internal P loading from the sediment in summer $[87,88]$. Nevertheless, the long-term increase in Secchi depth and the decrease in SS and Chl-a were strongest in summer in the S lakes, indicating significant water clarity improvements in summer despite the fact that the strongest decrease in phytoplankton biomass occurred in spring. However, eight Danish lakes (five included in the present study) showed no significant decline in phytoplankton biomass in either summer or autumn between 1989 and 2001. This probably reflects that the internal loading was stronger in the earlier period of nutrient reduction in the study lakes [70].

Overall, the widespread nutrient reduction in Danish lakes during the study period led to moderate synchrony of the temporal changes in lake chemistry and plankton, including a notable long-term increase in plankton richness in 17 lakes. The synchrony was strongest and the trends most consistent in lakes recovering from eutrophication, demonstrating the prominent role of re-oligotrophication in driving the increases in plankton diversity and changes in plankton composition. The analyses of plankton composition suggested that lake restoration efforts resulted in recovery of the plankton community composition. The potential effect of climate on synchrony and long-term trends in lake chemistry and plankton was modest, even in summer when the climate signal was strongest, probably being confounded by the more dominant effects of nutrient reduction. The present study indicates that anthropogenic changes in the agricultural landscape may act as a large-scale forcing mechanism and induce synchrony in ecosystems.

Acknowledgments: We are grateful for the work of numerous experts who performed the collection and counting of samples during two decades of monitoring. We consider this work a contribution of the Center for Informatics Research on Complexity in Ecology (CIRCE), funded by Aarhus University; Aarhus University Research Foundation under the AU IDEAS program and the EU FP-7 Theme 6. Project REFRESH (Adaptive Strategies to Mitigate the Impacts of Climate Change on European Freshwater Ecosystems, Contract No. 244121). We thank Anne Mette Poulsen for linguistic corrections and Lisbet Sortkjær for database assistance.

Author Contributions: Korhan Özkan, Erik Jeppesen and Jens-Christian Svenning conceived the idea; Korhan Özkan ran the statistical analyses; Rikke Bjerring and Liselotte S. Johansson helped collating the lake and plankton data; Thomas A. Davidson helped with the analyses; Martin Søndergaard, Torben L. Lauridsen and Erik Jeppesen supervised the lake monitoring; Korhan Özkan wrote the manuscript and all authors have contributed to its revisions.

Conflicts of Interest: The authors declare no conflict of interest. 


\section{Appendix A}

Table A1. Summary of data treatment for missing values in environmental variables. Frequencies of concurrent plankton and environmental samplings (original) and replacement with different averages are given. The lakes included in the analyses are: Bryrup Langsø, Søholm Sø, Hinge Sø, Arreskov Sø, Ravnsø, Vesterborg Sø, Arresø, Søby Sø Midtjylland, Maglesø V. Brorfelde, Hornum Sø, Østrup-Gundsømagle Sø, Norssø, Store Søgård Sø, Søgård Sø Jylland, Tissø, Holm Sø, Utterslev Mose.

\begin{tabular}{cccccc}
\hline & Original & One Week & Two Weeks & One Month & Missing \\
\hline $\mathrm{TP}$ & 0.97 & 0.015 & 0.005 & 0.005 & 0.005 \\
$\mathrm{PO}_{4}$ & 0.968 & 0.015 & 0.005 & 0.005 & 0.006 \\
$\mathrm{TN}$ & 0.969 & 0.015 & 0.005 & 0.006 & 0.006 \\
$\mathrm{NO}_{3-2}$ & 0.966 & 0.015 & 0.005 & 0.004 & 0.01 \\
$\mathrm{NH}_{4}$ & 0.968 & 0.015 & 0.005 & 0.006 & 0.006 \\
$\mathrm{pH}$ & 0.97 & 0.015 & 0.004 & 0.005 & 0.005 \\
$\mathrm{Alkalinity}$ & 0.956 & 0.015 & 0.005 & 0.007 & 0.018 \\
$\mathrm{Chl-a}$ & 0.964 & 0.015 & 0.005 & 0.007 & 0.009 \\
$\mathrm{SS}$ & 0.949 & 0.013 & 0.005 & 0.007 & 0.026 \\
Secchi & 0.963 & 0.006 & 0.004 & 0.005 & 0.021 \\
$\mathrm{SiO}$ & 0.967 & 0.015 & 0.005 & 0.007 & 0.007 \\
Water & 0.956 & 0.006 & 0.005 & 0.009 & 0.024 \\
Temperature & 0.884 & 0.006 & 0.004 & 0.01 & 0.096 \\
Schmidt & & & &
\end{tabular}

Table A2. Monotonic long-term trends using Kendall correlations in climate averaged for all lakes.

\begin{tabular}{ccccc}
\hline & Air Temperature & Irradiance & Precipitation & Wind Speed \\
\hline Whole & $0.05^{* * *}$ & $0.01 \mathrm{~ns}$ & $0.02^{*}$ & $-0.07^{* * *}$ \\
Spring & $0.05^{* * *}$ & $0.07^{* * *}$ & $-0.01 \mathrm{~ns}$ & $-0.10^{* * *}$ \\
Summer & $0.09^{* * *}$ & $-0.00 \mathrm{~ns}$ & $0.05^{* * *}$ & $-0.08^{* * *}$ \\
Autumn & $0.04^{* *}$ & $0.01 \mathrm{~ns}$ & $0.00 \mathrm{~ns}$ & $-0.05^{* *}$ \\
\hline
\end{tabular}

Notes: * denotes for statistical significance ${ }^{*} P<0.05 ;{ }^{* *} P<0.01$; $\left.{ }^{* * *} P<0.001\right) ;$ ns: denotes for not significant.

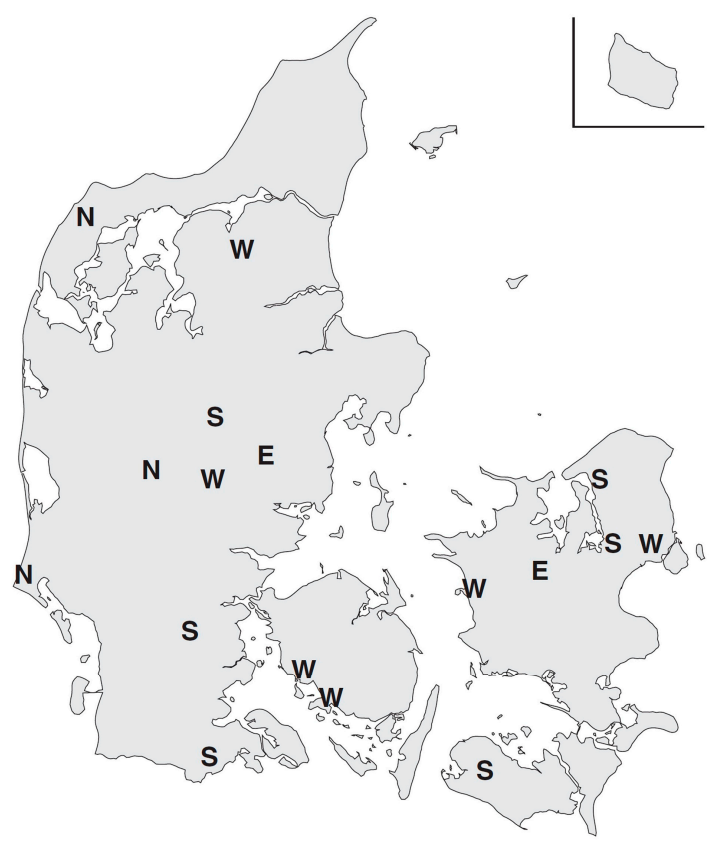

Figure A1. Map of Denmark and the location of the study lakes. Smaller panel at the upper-right corner shows Bornholm. S, W, N denote lake types (strong, weak and no TP decrease) and E denotes lakes not included in any of the groups. 


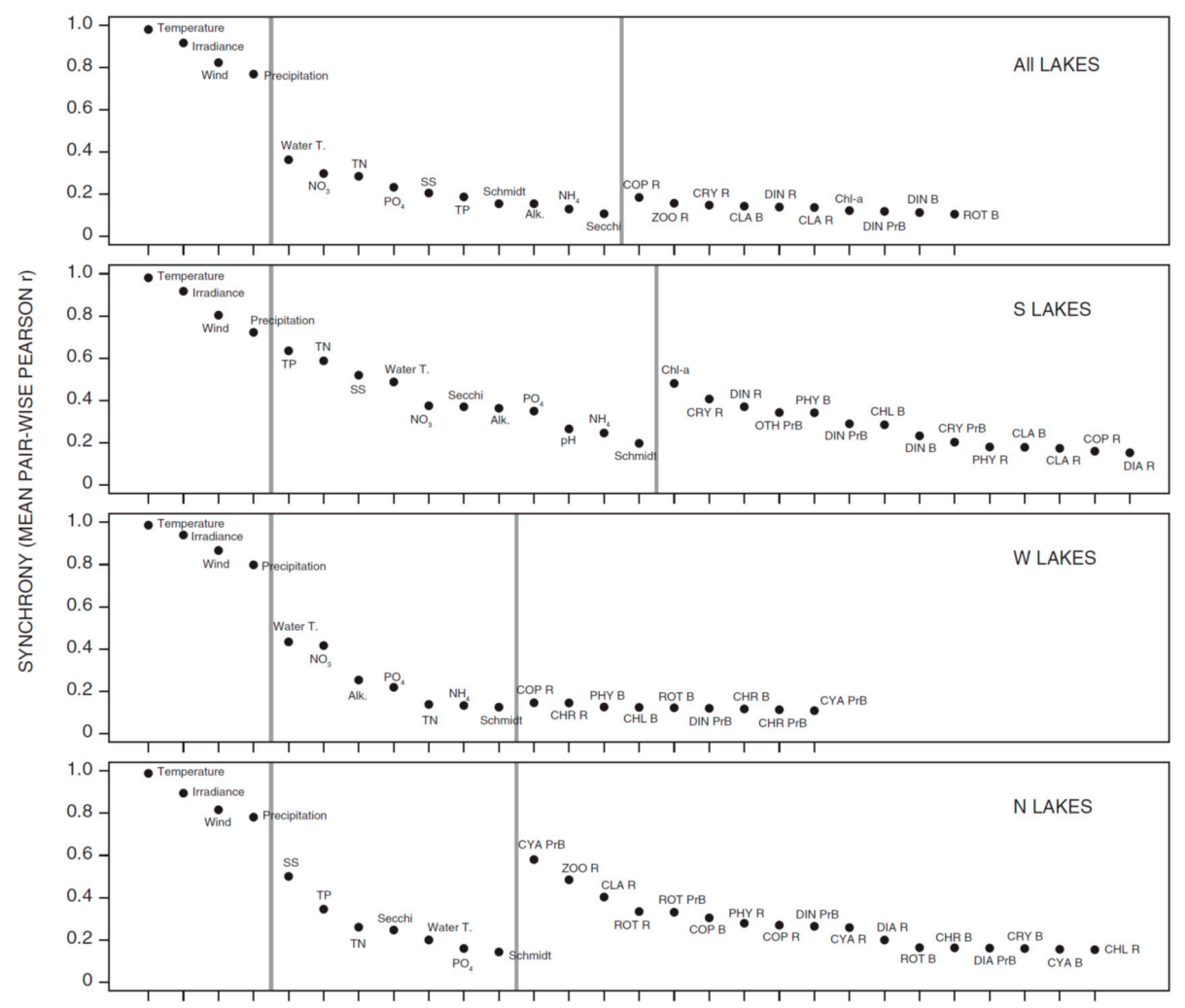

Figure A2. Summary of synchrony in climate, lake and plankton variables in spring analysed for all lakes and for S, W and N lakes separately. For details see Figure 3.

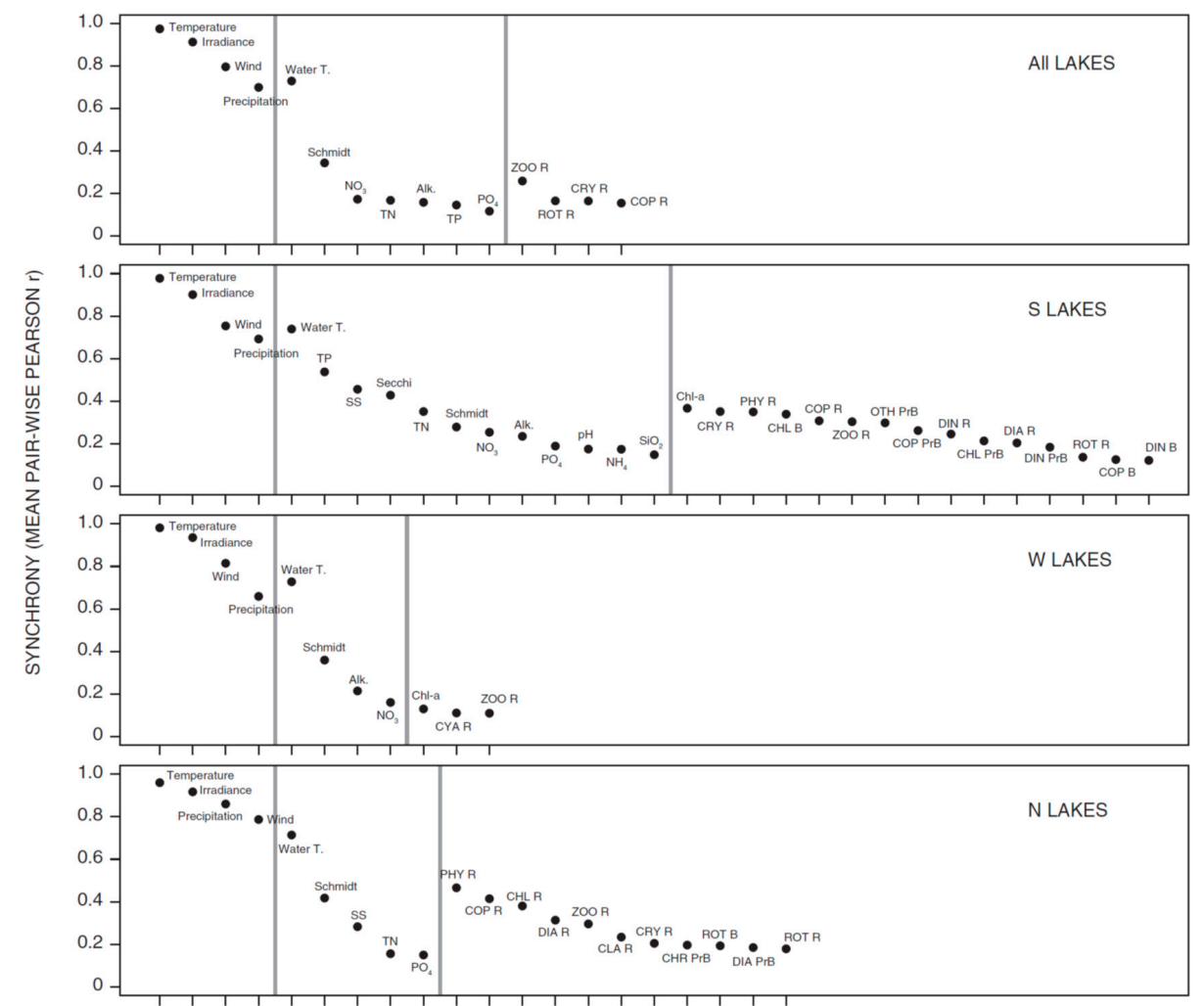

Figure A3. Summary of synchrony in climate, lake and plankton variables in summer analysed for all lakes and for S, W and N lakes separately. For details see Figure 3. 


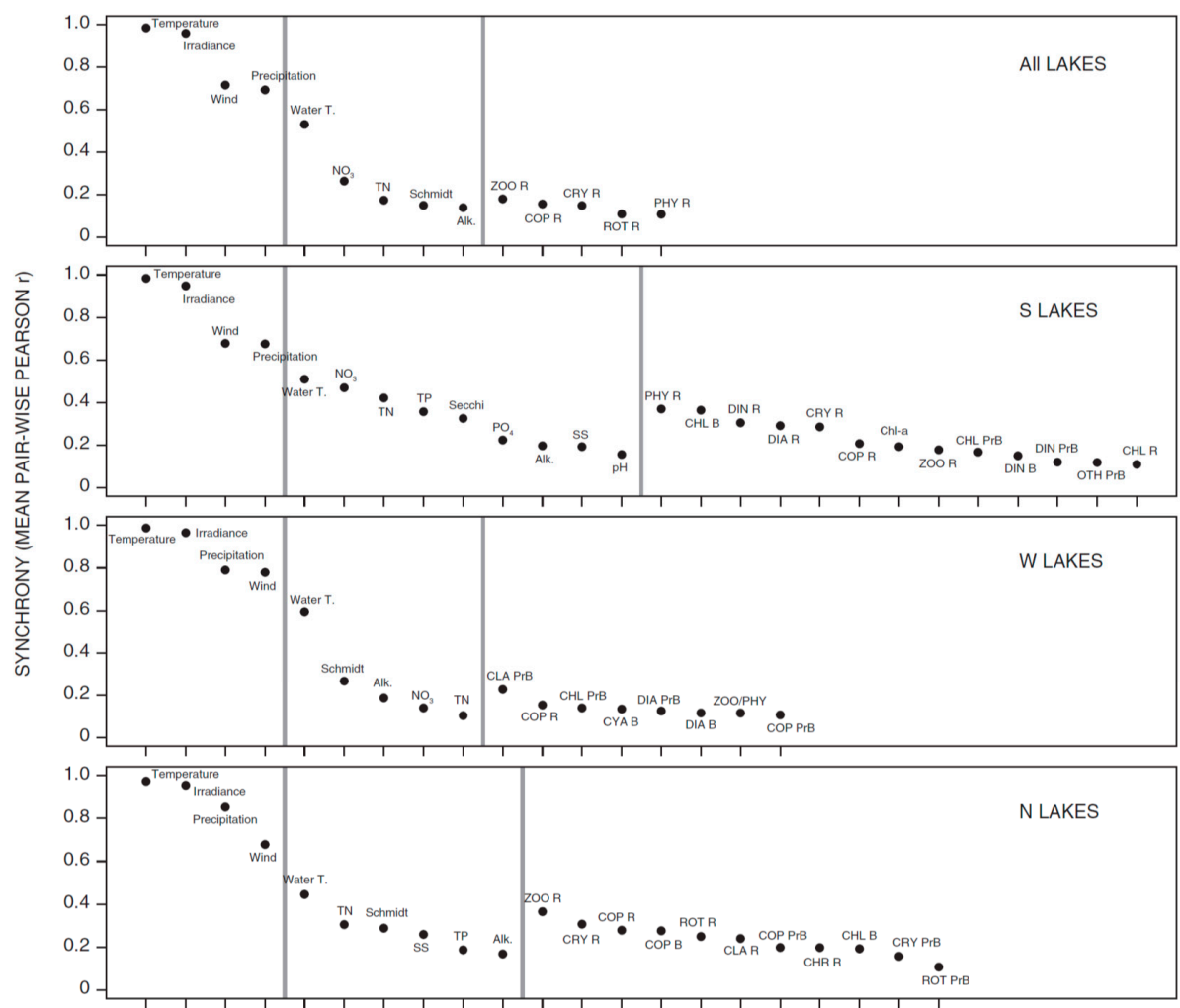

Figure A4. Summary of synchrony in climate, lake and plankton variables in autumn analysed for all lakes and for S, W and N lakes separately. For details see Figure 3.

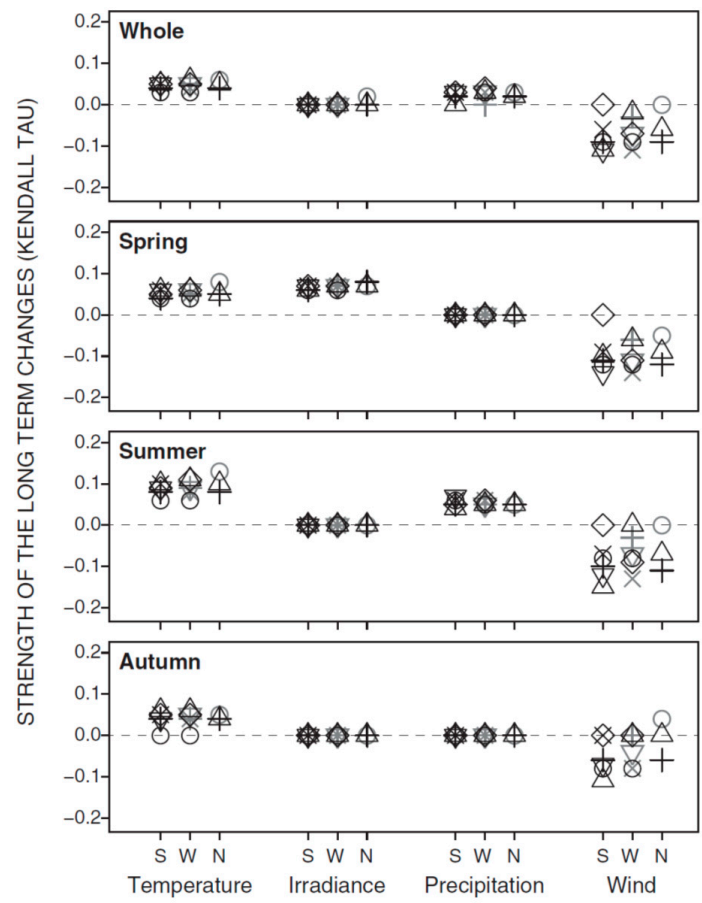

Figure A5. Summary of monotonic long-term trends in climatic parameters in each lake analysed for the whole year and for separate seasons. For details see Figures 2 and 4 in the text. 

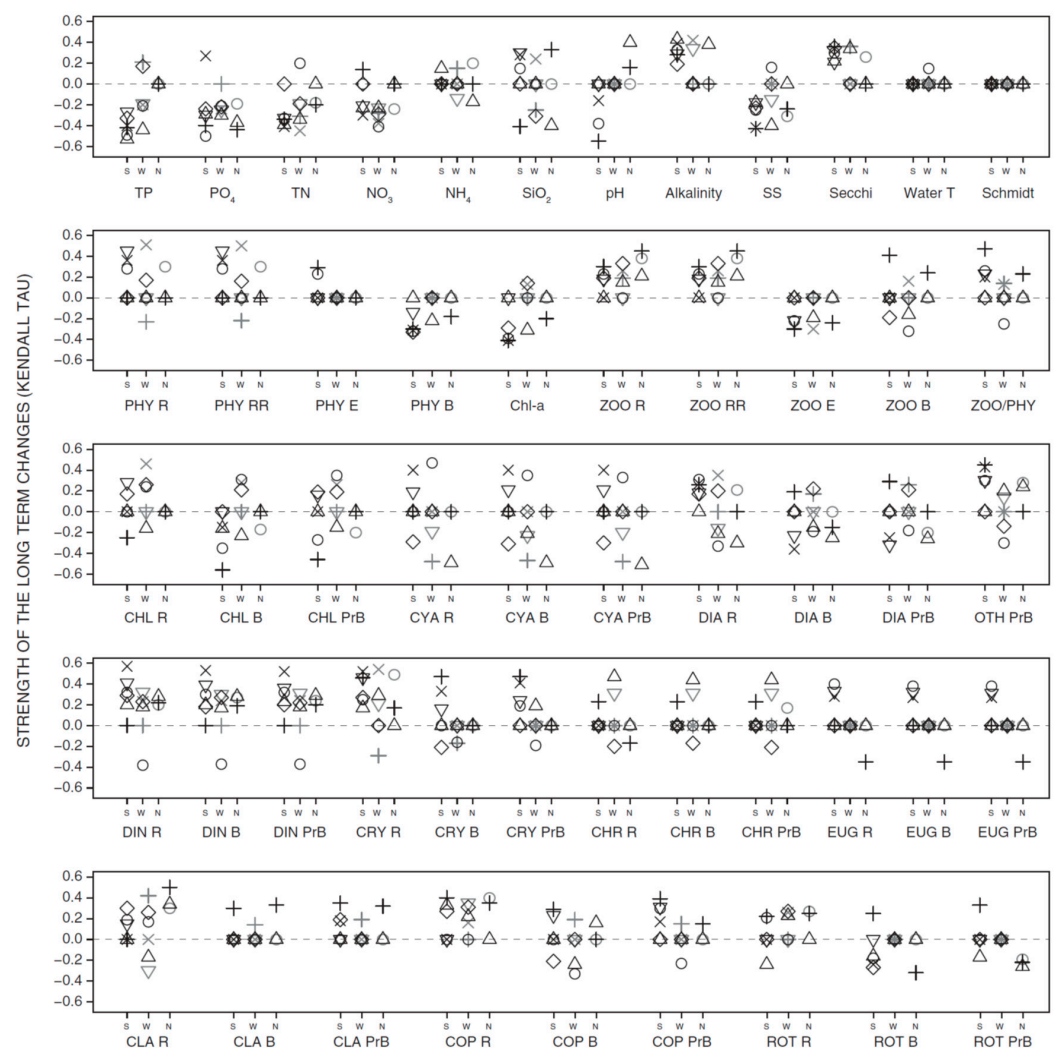

Figure A6. Summary of monotonic long-term trends in lake and plankton variables analysed for spring. For details see Figure 4.
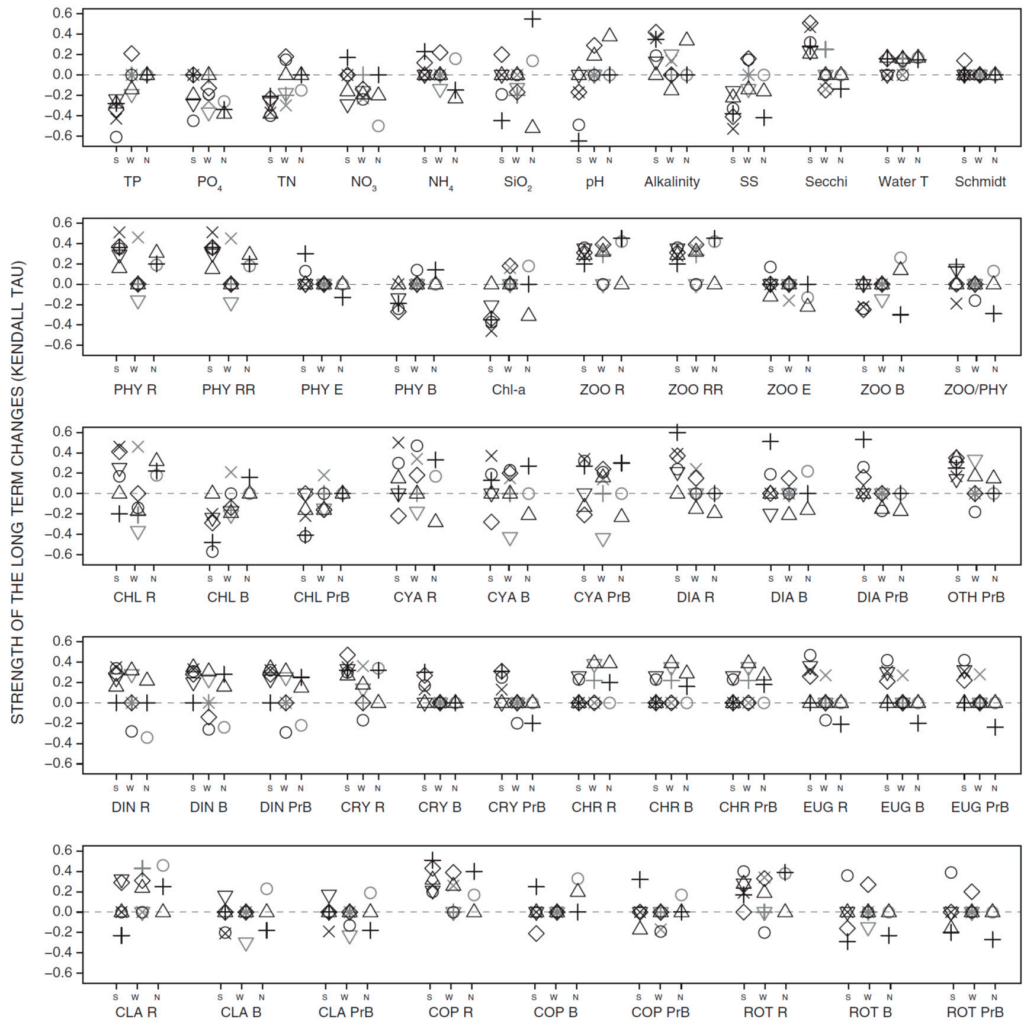

Figure A7. Summary of monotonic long-term trends in lake and plankton variables analysed for summer. For details see Figure 4. 

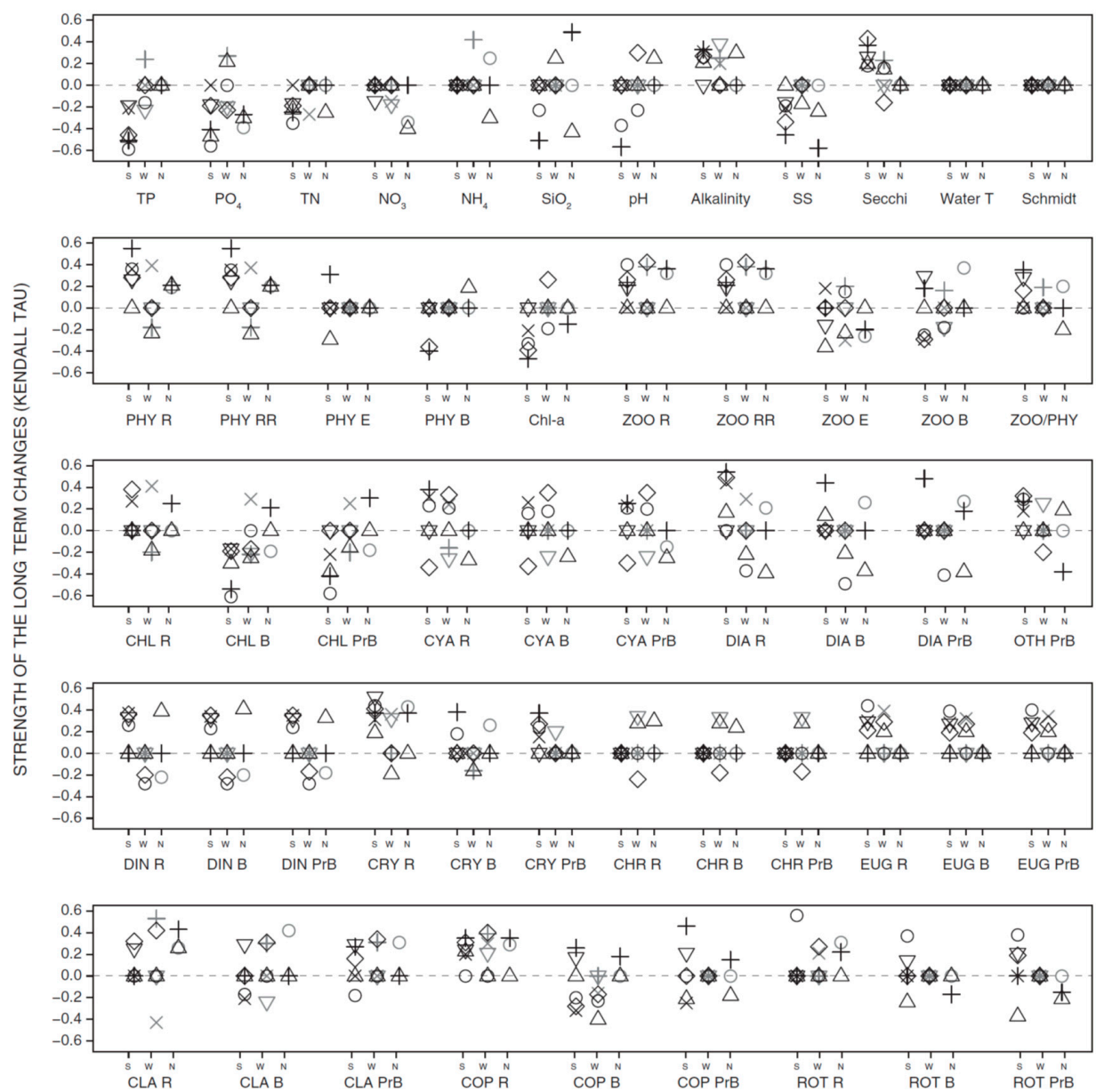

Figure A8. Summary of monotonic long-term trends in lake and plankton variables analysed for autumn. For details see Figure 4.

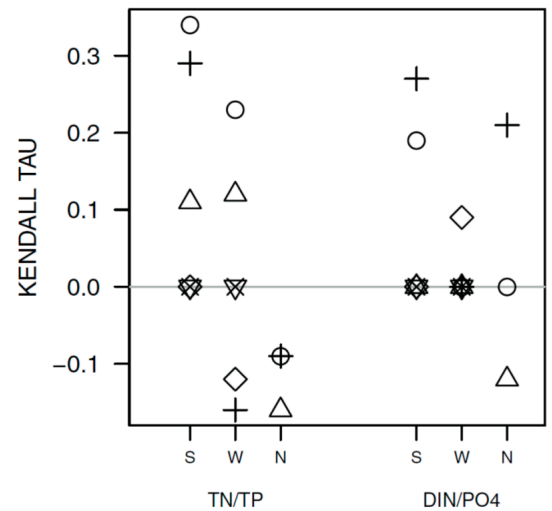

Figure A9. Summary of monotonic long-term trends in N:P ratios for both total and inorganic nutrient fractions. For details see Figure 4.

\section{References}

1. Isermann, K. Share of agriculture in nitrogen and phosphorus emissions into the surface waters of western-Europe against the background of their eutrophication. Fertil. Res. 1990, 26, 253-269. [CrossRef]

2. Smith, V.H.; Tilman, G.D.; Nekola, J.C. Eutrophication: Impacts of excess nutrient inputs on freshwater, marine, and terrestrial ecosystems. Environ. Pollut. 1999, 100, 179-196. [CrossRef] 
3. Cooke, G.D.; Welch, E.B.; Peterson, S.A.; Newroth, P.R. Restoration and Management of Lakes and Reservoirs, 2nd ed.; Lewis Publishers: Boca Raton, FL, USA, 1993.

4. Carpenter, S.R.; Ludwig, D.; Brock, W.A. Management of eutrophication for lakes subject to potentially irreversible change. Ecol. Appl. 1999, 9, 751-771. [CrossRef]

5. Jeppesen, E.; Søndergaard, M.; Jensen, J.P.; Havens, K.E.; Anneville, O.; Carvalho, L.; Coveney, M.F.; Deneke, R.; Dokulil, M.T.; Foy, B.; et al. Lake responses to reduced nutrient loading-An analysis of contemporary long-term data from 35 case studies. Freshw. Biol. 2005, 50, 1747-1771. [CrossRef]

6. Kernan, M.; Battarbee, R.W.; Moss, B. Climate Change Impacts on Freshwater Ecosystems; Wiley-Blackwell: Oxford, UK, 2010.

7. Vogt, R.J.; Rusak, J.A.; Patoine, A.; Leavitt, P.R. Differential effects of energy and mass influx on the landscape synchrony of lake ecosystems. Ecology 2011, 92, 1104-1114. [CrossRef] [PubMed]

8. Paerl, H.W.; Huisman, J. Blooms like it hot. Science 2008, 320, 57-58. [CrossRef] [PubMed]

9. Jeppesen, E.; Moss, B.; Bennion, H.; Friberg, N.; Gessner, M.O.; May, L. Chapter 6: Interaction of climate and eutrophication. In Changing Climate and Changing Freshwaters: A European Perspective; Kernan, M., Battarbee, R., Moss, B., Eds.; Wiley-Blackwell: Oxford, UK, 2009; pp. 119-151.

10. Moss, B.; Kosten, S.; Meerhoff, M.; Battarbee, R.W.; Jeppesen, E.; Mazzeo, N.; Havens, K.; Lacerot, G.; Liu, Z.W.; De Meester, L.; et al. Allied attack: Climate change and eutrophication. Inland Waters 2011, 1, 101-105. [CrossRef]

11. Schindler, D.W. The cumulative effects of climate warming and other human stresses on Canadian freshwaters in the new millennium. Can. J. Fish. Aquat. Sci. 2001, 58, 18-29. [CrossRef]

12. Smith, V.H.; Schindler, D.W. Eutrophication science: Where do we go from here? Trends Ecol. Evol. 2009, 24, 201-207. [CrossRef] [PubMed]

13. Köhler, J.; Hilt, S.; Adrian, R.; Nicklisch, A.; Kozerski, H.P.; Walz, N. Long-term response of a shallow, moderately flushed lake to reduced external phosphorus and nitrogen loading. Freshw. Biol. 2005, 50, 1639-1650. [CrossRef]

14. Anderson, N.J.; Jeppesen, E.; Søndergaard, M. Ecological effects of reduced nutrient loading (oligotrophication) on lakes: An introduction. Freshw. Biol. 2005, 50, 1589-1593. [CrossRef]

15. Anneville, O.; Souissi, S.; Gammeter, S.; Straile, D. Seasonal and inter-annual scales of variability in phytoplankton assemblages: Comparison of phytoplankton dynamics in three peri-alpine lakes over a period of 28 years. Freshw. Biol. 2004, 49, 98-115. [CrossRef]

16. Salmaso, N. Long-term phytoplankton community changes in a deep subalpine lake: Responses to nutrient availability and climatic fluctuations. Freshw. Biol. 2010, 55, 825-846. [CrossRef]

17. Arhonditsis, G.B.; Brett, M.T.; DeGasperi, C.L.; Schindler, D.E. Effects of climatic variability on the thermal properties of Lake Washington. Limnol. Oceanogr. 2004, 49, 256-270. [CrossRef]

18. Coats, R.; Perez-Losada, J.; Schladow, G.; Richards, R.; Goldman, C. The warming of Lake Tahoe. Clim. Chang. 2006, 76, 121-148. [CrossRef]

19. Livingstone, D.M. Impact of secular climate change on the thermal structure of a large temperate central European lake. Clim. Chang. 2003, 57, 205-225. [CrossRef]

20. Dokulil, M.T.; Jagsch, A.; George, G.D.; Anneville, O.; Jankowski, T.; Wahl, B.; Lenhart, B.; Blenckner, T.; Teubner, K. Twenty years of spatially coherent deepwater warming in lakes across europe related to the North Atlantic Oscillation. Limnol. Oceanogr. 2006, 51, 2787-2793. [CrossRef]

21. Jeppesen, E.; Kronvang, B.; Jørgensen, T.B.; Larsen, S.E.; Andersen, H.E.; Søndergaard, M.; Liboriussen, L.; Bjerring, R.; Johansson, L.S.; Trolle, D. Recent climate-induced changes in freshwaters in denmark. In Climatic Change and Global Warming of Inland Waters: Impacts and Mitigation for Ecosystems and Societies; Wiley-Blackwell: Oxford, UK, 2013; pp. 155-171.

22. Anderson, J.; Foy, R.H.; Engstrom, D.R.; Rippey, B.; Alamgir, F. Climate forcing of diatom productivity in a lowland, eutrophic lake: White lough revisited. Freshw. Biol. 2012, 57, 2030-2043. [CrossRef]

23. Pomati, F.; Matthews, B.; Jokela, J.; Schildknecht, A.; Ibelings, B.W. Effects of re-oligotrophication and climate warming on plankton richness and community stability in a deep mesotrophic lake. Oikos 2011, 121, 1317-1327. [CrossRef]

24. Thackeray, S.J.; Jones, I.D.; Maberly, S.C. Long-term change in the phenology of spring phytoplankton: Species-specific responses to nutrient enrichment and climatic change. J. Ecol. 2008, 96, 523-535. [CrossRef]

25. Meis, S.; Thackeray, S.J.; Jones, I.D. Effects of recent climate change on phytoplankton phenology in a temperate lake. Freshw. Biol. 2009, 54, 1888-1898. [CrossRef] 
26. Blenckner, T.; Adrian, R.; Livingstone, D.M.; Jennings, E.; Weyhenmeyer, G.A.; George, D.G.; Jankowski, T.; Jarvinen, M.; Aonghusa, C.N.; Noges, T.; et al. Large-scale climatic signatures in lakes across Europe: A meta-analysis. Glob. Chang. Biol. 2007, 13, 1314-1326. [CrossRef]

27. Anneville, O.; Gammeter, S.; Straile, D. Phosphorus decrease and climate variability: Mediators of synchrony in phytoplankton changes among European peri-alpine lakes. Freshw. Biol. 2005, 50, 1731-1746. [CrossRef]

28. Winder, M.; Reuter, J.E.; Schladow, S.G. Lake warming favours small-sized planktonic diatom species. Proc. R. Soc. B Biol. Sci. 2009, 276, 427-435. [CrossRef] [PubMed]

29. Edwards, M.; Richardson, A.J. Impact of climate change on marine pelagic phenology and trophic mismatch. Nature 2004, 430, 881-884. [CrossRef] [PubMed]

30. Winder, M.; Schindler, D.E. Climate change uncouples trophic interactions in an aquatic ecosystem. Ecology 2004, 85, 2100-2106. [CrossRef]

31. Dong, X.H.; Bennion, H.; Maberly, S.C.; Sayer, C.D.; Simpson, G.L.; Battarbee, R.W. Nutrients exert a stronger control than climate on recent diatom communities in Esthwaite water: Evidence from monitoring and palaeolimnological records. Freshw. Biol. 2012, 57, 2044-2056. [CrossRef]

32. Moss, B.; Barker, T.O.M.; Stephen, D.; Williams, A.E.; Balayla, D.J.; Beklioglu, M.; Carvalho, L. Consequences of reduced nutrient loading on a lake system in a lowland catchment: Deviations from the norm? Freshw. Biol. 2005, 50, 1687-1705. [CrossRef]

33. Nõges, P.; Mischke, U.; Laugaste, R.; Solimini, A. Analysis of changes over 44 years in the phytoplankton of Lake Võrtsjärv (Estonia): The effect of nutrients, climate and the investigator on phytoplankton-based water quality indices. Hydrobiologia 2010, 646, 33-48. [CrossRef]

34. Phillips, G.; Kelly, A.; Pitt, J.A.; Sanderson, R.; Taylor, E. The recovery of a very shallow eutrophic lake, 20 years after the control of effluent derived phosphorus. Freshw. Biol. 2005, 50, 1628-1638. [CrossRef]

35. Gaedke, U.; Ollinger, D.; Bäuerle, E.; Straile, D. The impact of the interannual variability in hydrodynamic conditions on the plankton development in Lake Constance in spring and summer. Adv. Limnol. 1998, 53, 565-585.

36. Adrian, R.; O’Reilly, C.M.; Zagarese, H.; Baines, S.B.; Hessen, D.O.; Keller, W.; Livingstone, D.M.; Sommaruga, R.; Straile, D.; Van Donk, E. Lakes as sentinels of climate change. Limnol. Oceanogr. 2009, 54, 2283. [CrossRef] [PubMed]

37. Christensen, M.R.; Graham, M.D.; Vinebrooke, R.D.; Findlay, D.L.; Paterson, M.J.; Turner, M.A. Multiple anthropogenic stressors cause ecological surprises in boreal lakes. Glob. Chang. Biol. 2006, 12, 2316-2322. [CrossRef]

38. Reiss, J.; Bridle, J.R.; Montoya, J.M.; Woodward, G. Emerging horizons in biodiversity and ecosystem functioning research. Trends Ecol. Evol. 2009, 24, 505-514. [CrossRef] [PubMed]

39. Arnott, S.E.; Keller, B.; Dillon, P.; Yan, N.; Paterson, M.; Findlay, D. Using temporal coherence to determine the response to climate change in boreal shield lakes. Environ. Monit. Assess. 2003, 88, 365-388. [CrossRef] [PubMed]

40. Magnuson, J.J.; Benson, B.J.; Kratz, T.K. Temporal coherence in the limnology of a suite of lakes in Wisconsin, USA. Freshw. Biol. 1990, 23, 145-159. [CrossRef]

41. Baines, S.B.; Webster, K.E.; Kratz, T.K.; Carpenter, S.R.; Magnuson, J.J. Synchronous behavior of temperature, calcium, and chlorophyll in lakes of Northern Wisconsin. Ecology 2000, 81, 815-825. [CrossRef]

42. Rusak, J.A.; Yan, N.D.; Somers, K.M.; McQueen, D.J. The temporal coherence of zooplankton population abundances in neighboring north-temperate lakes. Am. Nat. 1999, 153, 46-58. [CrossRef]

43. Fischer, J.M.; Frost, T.M.; Ives, A.R. Compensatory dynamics in zooplankton community responses to acidification: Measurement and mechanisms. Ecol. Appl. 2001, 11, 1060-1072. [CrossRef]

44. Jeppesen, E.; Søndergaard, M.; Kronvang, B.; Jensen, J.P.; Svendsen, L.M.; Lauridsen, T.L. Lake and catchment management in denmark. Hydrobiologia 1999, 396, 419-432. [CrossRef]

45. Svendsen, L.M.; van der Bijl, L.; Boutrup, S.; Norup, B. Novana. Det Nationale Program for Overvågning af Vandmiljøet og Naturen. Programbeskrivelse-del 2 (Report in Danish: The National Monitoring Programme of the Water Environment and Nature); National Environmental Research Institute: Maharashtra, India, 2004; p. 128.

46. Özkan, K.; Jeppesen, E.; Davidson, T.A.; Sondergaard, M.; Lauridsen, T.L.; Bjerring, R.; Johansson, L.S.; Svenning, J.C. Cross-taxon congruence in lake plankton largely independent of environmental gradients. Ecology 2014, 95, 2778-2788. [CrossRef]

47. Pielou, E.C. Ecological Diversity; John Wiley \& Sons: New York, NY, USA, 1975; p. 165. 
48. Lauridsen, T.L.; Søndergaard, M.; Jensen, J.P.; Jeppesen, E.; Jørgensen, T.B. Undersøgelser i Søer. NOVANA og DEVANO Overvågningsprogram (Report in Danish: Investigations in Lakes); Danmarks Miljøundersøgelser, Aarhus University: Aarhus, Denmark, 2007; p. 164.

49. Idso, S.B. On the concept of lake stability. Limnol. Oceanogr. 1973, 18, 681-683. [CrossRef]

50. Read, J.S.; Hamilton, D.P.; Jones, I.D.; Muraoka, K.; Winslow, L.A.; Kroiss, R.; Wu, C.H.; Gaiser, E. Derivation of lake mixing and stratification indices from high-resolution lake buoy data. Environ. Model. Softw. 2011, 26, 1325-1336. [CrossRef]

51. Mann, H.B. Nonparametric tests against trend. Econometrica 1945, 13, 245-259. [CrossRef]

52. Jeppesen, E.; Jensen, J.P.; Søndergaard, M. Response of phytoplankton, zooplankton, and fish to re-oligotrophication: An 11 year study of 23 Danish lakes. Aquat. Ecosyst. Health Manag. 2002, 5, 31-43. [CrossRef]

53. Wood, S.N. Generalized Additive Models: An Introduction with R; Chapman \& Hall/CRC: Boca Raton, FL, USA, 2006; p. 391.

54. Minchin, P.R. An evaluation of the relative robustness of techniques for ecological ordination. Vegetatio 1987, 69, 89-107. [CrossRef]

55. R Development Core Team. R: A Language and Environment for Statistical Computing; R Version 2.13.0; R Foundation for Statistical Computing: Vienna, Austria, 2011.

56. Oksanen, J.; Kindt, R.; Legendre, P.; O’Hara, B.; Simpson, G.L.; Solymos, P.; Henry, M.; Stevens, H.; Wagner, H. Vegan: Community Ecology Package; R Package Version 1.17-11. 2011. Available online: https:/ / cran.r-project. org/web/packages/vegan/index.html (accessed on 26 September 2016).

57. McLeod, A.I. Kendall: Kendall Rank Correlation and Mann-Kendall Trend Test; R Package Version 2.2. 2011. Available online: https://cran.r-project.org/web/packages/Kendall/index.html (accessed on 26 September 2016).

58. Winder, M.; Cloern, J.E. The annual cycles of phytoplankton biomass. Philos. Trans. R. Soc. B 2010, 365, 3215-3226. [CrossRef] [PubMed]

59. Gerten, D.; Adrian, R. Differences in the persistency of the North Atlantic Oscillation signal among lakes. Limnol. Oceanogr. 2001, 46, 448-455. [CrossRef]

60. Huber, V.; Wagner, C.; Gerten, D.; Adrian, R. To bloom or not to bloom: Contrasting responses of cyanobacteria to recent heat waves explained by critical thresholds of abiotic drivers. Oecologia 2012, 169, 245-256. [CrossRef] [PubMed]

61. Wagner, C.; Adrian, R. Consequences of changes in thermal regime for plankton diversity and trait composition in a polymictic lake: A matter of temporal scale. Freshw. Biol. 2011, 56, 1949-1961. [CrossRef]

62. Winder, M.; Schindler, D.E. Climatic effects on the phenology of lake processes. Glob. Chang. Biol. 2004, 10, 1844-1856. [CrossRef]

63. Nielsen, A.; Trolle, D.; Søndergaard, M.; Lauridsen, T.L.; Bjerring, R.; Olesen, J.E.; Jeppesen, E. Watershed land use effects on lake water quality in Denmark. Ecol. Appl. 2012, 22, 1187-1200. [CrossRef] [PubMed]

64. Kronvang, B.; Andersen, H.E.; Borgesen, C.; Dalgaard, T.; Larsen, S.E.; Bogestrand, J.; Blicher-Mathiasen, G. Effects of policy measures implemented in Denmark on nitrogen pollution of the aquatic environment. Environ. Sci. Policy 2008, 11, 144-152. [CrossRef]

65. Jeppesen, E.; Kronvang, B.; Olesen, J.E.; Audet, J.; Søndergaard, M.; Hoffmann, C.C.; Andersen, H.E.; Lauridsen, T.L.; Liboriussen, L.; Larsen, S.E.; et al. Climate change effects on nitrogen loading from cultivated catchments in Europe: Implications for nitrogen retention, ecological state of lakes and adaptation. Hydrobiologia 2011, 663, 1-21. [CrossRef]

66. Finlay, J.C.; Small, G.E.; Sterner, R.W. Human influences on nitrogen removal in lakes. Science 2013, 342, 247-250. [CrossRef] [PubMed]

67. Weyhenmeyer, G.A.; Jeppesen, E.; Adrian, R.; Arvola, L.; Blenckner, T.; Jankowski, T.; Jennings, E.; Noges, P.; Noges, T.; Straile, D. Nitrate-depleted conditions on the increase in shallow Northern European lakes. Limnol. Oceanogr. 2007, 52, 1346-1353. [CrossRef]

68. Bloch, I.; Weyhenmeyer, G.A. Long-term changes in physical and chemical conditions of nutrient-poor lakes along a latitudinal gradient: Is there a coherent phytoplankton community response? Aquat. Sci. 2012, 74, 77-85. [CrossRef]

69. George, D.G.; Talling, J.F.; Rigg, E. Factors influencing the temporal coherence of five lakes in the English Lake District. Freshw. Biol. 2000, 43, 449-461. [CrossRef] 
70. Jeppesen, E.; Jensen, J.P.; Søndergaard, M.; Lauridsen, T.L. Response of fish and plankton to nutrient loading reduction in eight shallow Danish lakes with special emphasis on seasonal dynamics. Freshw. Biol. 2005, 50, 1616-1627. [CrossRef]

71. Gutierrez, M.F.; Devercelli, M.; Brucet, S.; Lauridsen, T.L.; Søndergaard, M.; Jeppesen, E. Is recovery of large-bodied zooplankton after nutrient loading reduction hampered by climate warming? A long-term study of shallow hypertrophic Lake Søbygaard, Denmark. Water 2016, 8. [CrossRef]

72. Alric, B.; Jenny, J.-P.; Berthon, V.; Arnaud, F.; Pignol, C.; Reyss, J.-L.; Sabatier, P.; Perga, M.-E. Local forcings affect lake zooplankton vulnerability and response to climate warming. Ecology 2013, 94, 2767-2780. [CrossRef] [PubMed]

73. Kronvang, B.; Jeppesen, E.; Conley, D.J.; Søndergaard, M.; Larsen, S.E.; Ovesen, N.B.; Carstensen, J. Nutrient pressures and ecological responses to nutrient loading reductions in Danish streams, lakes and coastal waters. J. Hydrol. 2005, 304, 274-288. [CrossRef]

74. Özkan, K.; Jeppesen, E.; Johansson, L.S.; Beklioglu, M. The response of periphyton and submerged macrophytes to nitrogen and phosphorus loading in shallow warm lakes: A mesocosm experiment. Freshw. Biol. 2010, 55, 463-475. [CrossRef]

75. Gonzalez Sagrario, M.A.; Jeppesen, E.; Gomá, J.; Søndergaard, M.; Jensen, J.P.; Lauridsen, T.; Landkildehus, F. Does high nitrogen loading prevent clear-water conditions in shallow lakes at moderately high phosphorus concentrations? Freshw. Biol. 2005, 50, 27-41. [CrossRef]

76. James, C.; Fisher, J.; Russell, V.; Collings, S.; Moss, B. Nitrate availability and hydrophyte species richness in shallow lakes. Freshw. Biol. 2005, 50, 1049-1063. [CrossRef]

77. Özkan, K.; Jeppesen, E.; Søndergaard, M.; Lauridsen, T.; Liboriussen, L.; Svenning, J.-C. Contrasting roles of water chemistry, lake morphology, land-use, climate and spatial processes in driving phytoplankton richness in the Danish landscape. Hydrobiologia 2013, 710, 173-187. [CrossRef]

78. Tilman, D.; Pacala, S. The maintenance of species richness in plant communities. In Species Diversity in Ecological Communities; Ricklefs, R.E., Schluter, D., Eds.; University of Chicago Press: Chicago, IL, USA, 1993; pp. 13-25.

79. Tilman, D.; Kilham, S.S.; Kilham, P. Phytoplankton community ecology-The role of limiting nutrients. Annu. Rev. Ecol. Syst. 1982, 13, 349-372. [CrossRef]

80. Guisande, C.; Bartumeus, F.; Ventura, M.; Catalan, J. Role of food partitioning in structuring the zooplankton community in mountain lakes. Oecologia 2003, 136, 627-634. [PubMed]

81. Striebel, M.; Singer, G.; Stibor, H.; Andersen, T. "Trophic overyielding": Phytoplankton diversity promotes zooplankton productivity. Ecology 2012, 93, 2719-2727. [CrossRef] [PubMed]

82. Declerck, S.; Vandekerkhove, J.; Johansson, L.; Muylaert, K.; Conde-Porcuna, J.M.; Van der Gucht, K.; Pérez-Martínez, C.; Lauridsen, T.; Schwenk, K.; Zwart, G.; et al. Multi-group biodiversity in shallow lakes along gradients of phosphorus and water plant cover. Ecology 2005, 86, 1905-1915. [CrossRef]

83. Declerck, S.; Vanderstukken, M.; Pals, A.; Muylaert, K.; de Meester, L. Plankton biodiversity along a gradient of productivity and its mediation by macrophytes. Ecology 2007, 88, 2199-2210. [CrossRef] [PubMed]

84. Kruk, C.; Rodriguez-Gallego, L.; Meerhoff, M.; Quintans, F.; Lacerot, G.; Mazzeo, N.; Scasso, F.; Paggi, J.C.; Peeters, E.T.H.M.; Marten, S. Determinants of biodiversity in subtropical shallow lakes (Atlantic coast, Uruguay). Freshw. Biol. 2009, 54, 2628-2641. [CrossRef]

85. Muylaert, K.; Perez-Martinez, C.; Sanchez-Castillo, P.; Lauridsen, T.L.; Vanderstukken, M.; Declerck, S.A.J.; Van der Gucht, K.; Conde-Porcuna, J.M.; Jeppesen, E.; De Meester, L.; et al. Influence of nutrients, submerged macrophytes and zooplankton grazing on phytoplankton biomass and diversity along a latitudinal gradient in Europe. Hydrobiologia 2010, 653, 79-90. [CrossRef]

86. Straile, D.; Jochimsen, M.; Kümmerlin, R. The use of long-term monitoring data for studies of planktonic diversity: A cautionary tale from two Swiss lakes. Freshw. Biol. 2013, 58, 1292-1301. [CrossRef]

87. Søndergaard, M.; Jensen, J.P.; Jeppesen, E. Seasonal response of nutrients to reduced phosphorus loading in 12 Danish lakes. Freshw. Biol. 2005, 50, 1605-1615. [CrossRef]

88. Søndergaard, M.; Bjerring, R.; Jeppesen, E. Persistent internal phosphorus loading during summer in shallow eutrophic lakes. Hydrobiologia 2012, 710, 95-107. [CrossRef]

(c) 2016 by the authors; licensee MDPI, Basel, Switzerland. This article is an open access article distributed under the terms and conditions of the Creative Commons Attribution (CC-BY) license (http://creativecommons.org/licenses/by/4.0/). 